\title{
Affect-Loaded Questions in Japanese Storytelling: An Analysis of Grammar, Prosody, and Body Movements of Story Recipients' Questions
}

\author{
Chisato Koike \\ Department of Modern Languages and Literatures, California State University, Los Angeles, CA, USA \\ Email: ckoike@calstatela.edu
}

Received 21 September 2015; accepted 26 October 2015; published 29 October 2015

Copyright (C) 2015 by author and Scientific Research Publishing Inc.

This work is licensed under the Creative Commons Attribution International License (CC BY).

http: //creativecommons.org/licenses/by/4.0/

(c) (i) Open Access

\section{Abstract}

The present study explores affective stance in conversational storytelling by investigating the ways in which unknowing story recipients display affective stances toward a teller's story through questions that deploy multimodal resources. The data are based on videotaped natural faceto-face conversations between native Japanese speakers. While unknowing story recipients ask questions of the storyteller only to elicit factual information ("neutral questions"), they also ask questions layered with affect ("affect-loaded questions"). Building on studies on affect and stance, assessment, questions, and alignment and affiliation in storytelling, I demonstrate how unknowing story recipients ask affect-loaded questions to elicit and display affective stances toward story contents by exploiting linguistic and non-linguistic resources. First, I explicate how unknowing story recipients employ not only linguistic devices (e.g., emotion words, wh-questions, and deictic expressions such as sonna "like that"), but also prosody, facial expressions, body movements, and pre-/concurrent-laughter in order to load questions with affective stance that display, for example, disgust, humor, sarcasm, criticism, or surprise. Secondly, I show how unknowing story recipients use rhetorical questions to express their affect (rather than to elicit information from the storyteller). Thirdly, I demonstrate how affiliation of affective stance between storyteller and unknowing story recipients influences the trajectory of storytelling and how the participants negotiate their affective stances. This study sheds light on the interactional process of how participants in talk-in-interaction display affective stance through a range of multimodal resources, by examining how unknowing story recipients ask affect-loaded questions of the storyteller. It illuminates the social practice of story recipients' active participation in storytelling activity that is embedded in social interaction, through their use of questions that dynamically co-construct and negotiate affective stance. 
Keywords

Affect, Questions, Storytelling, Affiliation, Japanese Conversations

\section{Introduction}

This study investigates affect in Japanese storytelling, focusing on how "unknowing" story recipients, who are "possible recipient[s] not expected to know about an event being reported by a speaker" (Goodwin, 1979: p. 100), elicit affective stance from a storyteller or display their own affective stance toward the story or the storyteller through questions deploying multimodal resources. The storyteller in conversational storytelling often tells his or her story about past events not merely to recount what exactly happened in these events, but also to vent his or her intensified emotions, such as joy or frustration. As Ochs and Capps (2001) pointed out, in conversational narratives of personal experience, "[t]he central narrated events tend to be sources of some combination of fear, frustration, misunderstanding or confusion, irritation, shame or disapproval, malaise, and sympathy” (p. 146).

Though the storyteller's affective stance ${ }^{1}$ is explicitly and voluntarily expressed in the course of storytelling, it is also disclosed by unknowing story recipients' active participation through their responses, comments, and questions during storytelling. However, how unknowing story recipients contribute to storytelling in bringing out the storyteller's affective stance during storytelling has not been fully examined thus far. In this study, I will explore displays of affective stance in storytelling, the functions and multimodal aspects of "affect-loaded questions", which I define as questions layered with affect, and the participation frameworks of storytelling in conversations, using videotaped natural face-to-face conversations between native speakers of Japanese.

First, I will illustrate how unknowing story recipients 1) use "neutral questions" merely to elicit factual information that they do not have and 2) ask affect-loaded questions either to elicit other participants' affect or to display their own affect, as they request factual information. I will then examine how unknowing story recipients employ not only linguistic devices, but also prosody, facial expressions, body movements, and laughter in order to color questions with various types of affect. I will also analyze how the unknowing story recipients use rhetorical questions not to elicit information, but rather to express their own affect. Finally, I will demonstrate how affiliation and disaffiliation of affective stance between the storyteller and unknowing story recipients influence the sequential organization of storytelling.

\section{Previous Studies}

\subsection{Previous Studies on Questions}

One of the major research purposes of this study is investigating how questions in conversations not only function to elicit information from other participants but also serve to display and elicit affect. Questions have long been the subject of study and of controversy in the fields of syntax, semantics, and pragmatics, in English (in pragmatics e.g., Hayano, 2013; Heritage, 2002; Koshik, 2005; Raymond, 2003; Weber, 1993) and in Japanese (e.g., Adachi, 1999; Hayashi, 2010; Minami, 1985; Miyazaki, 2005; Moriyama, 1989), among which Hayashi’s (2010) survey of the question-response system in Japanese conversations offered a base for some of the analyses in the present study. According to Hayashi (2010), "functional questions" are "questions that are produced to seek information, confirmation, or agreement", and are distinct from "those that are interrogatively formatted but do not appear to seek a response (e.g., rhetorical questions)” (p. 2685). In the present study (Section 3.5), I will consider rhetorical questions more in detail, examining their function of displaying a questioner's affective stance and analyzing how not only their format but also their accompanying non-linguistic aspects contribute to their being construed as rhetorical questions that do not seek a response. Hayashi (2010) also pointed out that in addition to tag-type questions, "a negatively-formatted polar question is used to convey an assertion of the opposite polarity, i.e., affirmative, while seeking agreement from the addressee” (p. 2697). I will examine how the

\footnotetext{
${ }^{1}$ Ochs (1996) pointed out that situational dimensions include social identity, social acts, activity (e.g., storytelling), epistemic stance, and affective stance, and she defined affective stance as "a mood, attitude, feeling, and disposition, as well as degrees of emotional intensity vis-à-vis some focus of concern” (p. 410).
} 
negative question is layered with affect and is used to elicit and display affective stance in storytelling. While most of the previous studies on questions examined the forms, meanings, functions, and social actions of questions with regard to syntactic structures or the epistemic status of participants, this study intends to reveal how unknowing story recipients layer their questions with their affect by examining talk, prosody, and body movements.

\subsection{Previous Studies on Affect}

Accordingly, the second major research goal of this study is to explicate how affect is displayed in Japanese storytelling through multimodal resources such as language, prosody, facial expressions ${ }^{2}$, and body movements. Among a considerable number of studies on affect and stance in English conversations (e.g., Besnier, 1990; Du Bois, 2007; Goodwin, 2007; Goodwin, 2006; Goodwin, Cekaite, \& Goodwin, 2012; Ochs \& Schieffelin, 1989; Wilce, 2009), Goodwin's (2007) analysis provided the key to an understanding of how affective stance is displayed through the participation frameworks created by the participants' bodies. Goodwin (2007) revealed that "the alignment of participants toward each other generates at least five different kinds of stance": instrumental, epistemic, cooperative, moral, and affective (pp. 70-71), and demonstrated how participation frameworks are organized with respect to instrumental and epistemic stances and how they structure cooperative, moral, and affective stances in talk-in-interaction.

Goodwin et al. (2012) analyzed the sequence in an interaction among four girls in which the participants expressed the emotion of disgust, and found that the participants displayed their "oppositional alignment" (as opposed to "congruent alignment") toward the target of their expressive behavior (e.g., a person considered to be disgusting) by "dramatically turn[ing] their faces and upper bodies away from" the target (p. 22). They stressed that bodily displayed alignments as such "are being defined not in terms of the behavior of a single isolated body, but instead with reference to how one actor's body aligns with others' bodies and proposed course of action" (Goodwin et al., 2012: p. 22). Drawing upon these studies, the present study investigates the participants' affective stance by examining their bodily displayed alignment with other participants during storytelling sequences.

Thus far, few studies have examined affect in Japanese conversations. Maynard's (2002) insightful analysis of two types of interrogatives provided a point of departure for the present study. She identified "informational interrogatives' that seek information-providing answers and 'emotive interrogatives' that seek no such answers" (p. 247). Emotive interrogatives include "(1) self-inquiry, (2) self-acceptance, (3) metacommunicative interrogatives... and (4) the so-called rhetorical question" (p. 251). In my analysis, I use the term "affect-loaded questions" and demonstrate that these double-barreled questions can request information and display affect at the same time. Ono's (2006) analysis of utterances in the non-predicate-final order offered important means to examine emotions in terms of prosody and word order. He pointed out that non-predicate-final utterances (e.g., adjectives + demonstratives) uttered in one intonation unit are "emotionally charged utterances" (p. 143). Hasegawa's (2006) analysis of soliloquy is also relevant to my analysis of self-directed rhetorical questions. She pointed out that embedding soliloquy in conversations can express two different affective stances simultaneously: deference and intimacy.

\subsection{Previous Studies on Storytelling}

The third thread of this study explores the ways in which unknowing story recipients' affect-loaded questions influence the sequences of storytelling. A large number of studies have examined the sequential organization of storytelling in conversations (e.g., Goodwin, 1984, 1986; Goodwin, 1990; Jefferson, 1984a, 1984b; Labov, 1972; Maynard, 1989; Ochs \& Capps, 2001; Sacks, 1974, 1992; Tannen, 1984). However, to date no studies have fully examined story recipients' contributions to the organization of storytelling and affect in storytelling while focusing on one particular practice. In this study, I will analyze how the unknowing story recipients' practice of asking affect-loaded questions brings various interactional consequences to the sequential organization of story and the participation frameworks, using the notion of "affiliation" (Couper-Kuhlen, 2012; Lindström \& Sorjonen, 2013; Stivers, 2008) of affective stance.

In her analysis of storytelling in American-English conversations, Stivers (2008) proposed the notions of

\footnotetext{
${ }^{2}$ See Ruusuvuori and Peräkylä (2009) for an analysis of how facial expressions are used for assessment in storytelling.
} 
"alignment” and "affiliation”. The term "alignment" is used when a recipient "supports the structural asymmetry of the storytelling activity: that a storytelling is in progress and the teller has the floor until story completion", and "[d]isaligned actions undermine this asymmetry by competing for the floor or failing to treat a story as either in progress or-at story completion-as over" (p. 34). On the other hand, the term "affiliation" is used when "the hearer displays support of and endorses the teller's conveyed stance", and "preferred and affiliative uptake involves taking a stance that matches the teller's stance toward the event(s) being described as, for example, funny, sad, horrible, or exciting”3 (pp. 35-36).

Couper-Kuhlen (2012) analyzed English conversational complaint stories, and found that "claims of understanding, stance-congruent negative assessments, and by-proxy justifications are used in responding affiliatively to displays of anger and indignation in complaint stories, while factual follow-up questions, minimal responses, and withholdings are found in non-affiliative responses" (p. 132). The present study expands the notions of alignment and affiliation and uses these terms to refer to the alignment of storytelling activity and the affiliation of stance based on the mutual orientation of the storyteller and the story recipients, because conversational storytelling is collaboratively co-constructed by both the storyteller and the story recipients. I will examine affiliation of affective stance between the storyteller and the unknowing story recipients, explicating how affiliation or disaffiliation of affective stance influences the trajectory of storytelling and how their affective stance is negotiated in the storytelling activity.

\subsection{Previous Studies on Assessment}

Lastly, Goodwin and Goodwin’s (1992) “assessment”, i.e., "evaluating in some fashion persons and events being described within their talk” (p. 154) provides a crucial concept in this study, as unknowing story recipients frequently use affect-loaded questions for assessment about an "assessable" in the story, that is, "the entity being evaluated by an assessment” (Goodwin \& Goodwin, 1992: p. 156). With regard to affect in assessment, Goodwin and Goodwin (1992) acutely pointed out as follows:

Affect displays are not only pervasive in the organization of assessments, but also quite central to their organization. Moreover, public structures such as this which display the experience of one participant provide resources for the interactive organization of co-experience, a process that can be accomplished and negotiated in fine detail within assessments. (p. 155)

Building on these studies on storytelling, questions, affective stance, affiliation, and assessment, I demonstrate how unknowing story recipients ask affect-loaded questions, elicit affective stance from the storyteller, and display their affective stance toward story contents and the storyteller by exploiting linguistic and nonlinguistic resources in storytelling sequences, and how these affect-loaded questions contribute to the organization of storytelling and the participation frameworks in talk-in-interaction.

\section{Analysis}

I will clarify the underpinnings of my analysis by first showing the differences between "neutral questions" and "affect-loaded questions" (Section 3.1). I will then proceed to analyze how unknowing story recipients elicit the storyteller's affective stance about the story events and/or display their own affective stance toward stories through affect-loaded questions by examining their use of emotion words (Section 3.2), interjections, prosody, body movements (Section 3.3), laughter (Section 3.4), and rhetorical questions (Section 3.5). In Section 3.6, I also examine how affiliated or disaffiliated unknowing story recipients' affect-loaded questions sequentially influence the storyteller's story organization. Storytelling in the present study is defined as follows: "a coherent sequence of turns in which speakers recount past events that they experienced firsthand or secondhand in talk-in-interaction with the participants” (Koike, 2009). Out of 35 hours of conversations I recorded, 251 segments were identified as storytelling and analyzed for this research. Among them, storytelling segments that had unknowing story recipients' affect-loaded questions were selected for the present study. The data in this analysis are cited using two or three lines for each utterance: the first line gives the utterance in the Romanized transcrip-

\footnotetext{
${ }^{3}$ Stivers (2008) uses the term "stance" "to mean the teller's affective treatment of the events he or she is describing whether that is communicated explicitly or implicitly” (p. 37).
} 
tion, an optional second line provides a word-for-word gloss for each word in the Romanized utterance (only for the unknowing story recipients' questions that are the focus for each analysis), and the third line, an English translation. Transcription conventions and abbreviations used in the word-for-word gloss are provided in the Appendix.

\subsection{Neutral Questions vs. Affect-Loaded Questions in Storytelling}

Before closely examining various aspects of affect-loaded questions starting in Section 3.2, I will illustrate how neutral questions (Excerpts 1 and 2) and affect-loaded questions (Excerpts 3 and 4) differ in storytelling sequences. In Excerpt 1, Nobuko tells about her experience with eye surgery, during which she had a small crystal lump removed by an eye doctor. While Nobuko tells her story, the unknowing story recipient Yoshimi asks neutral questions twice.

Excerpt 1: Eye Doctor (neutral questions)

52 Nobuko: $\quad$ koo ba:: tto hikari aterarete mien yoo-ni shite >nan te yuu-no.< hari mitai-na $n$ [de, (he) put a light (on me) like this so that (I) don’t see (anything), and what should (I) say? With a thing like a needle,

53 Kyoko: [un.

$$
\text { Uh-huh. }
$$

$54 \rightarrow$ Yoshimi: $\quad$ itakatta?

hurt:PT

Did (it) hurt?

55 Nobuko: itakatta na:. nanka ma isshun ya[tta kedo:,

(It) hurt. Well, (it) was just a moment, but,

56 Yoshimi:

[un.

Uh-huh.

57 Nobuko: kowai yan. me: [akete-te.

(It)'s scary, you know? With (my) eyes open.

58 Yoshimi:

[kowai. un.

(It)’s scary. Yeah.

59 Nobuko: masui toka yutte mo sonna na:

Even though (I was under) anesthesia, like that, you know?

60 Yoshimi: u:n.

Uh-huh.

61 Nobuko: are de,

is that, and,

62 Kyoko: atashi [akan wa. me: kowai wa:

I'm no good with eyes. (It)'s scary.

63 Nobuko: [kowakatta wa: me:. de toreta yatsu: (0.2) mise[rarete:, 
(It) was scary. (My) eyes. And, (he) showed the thing that came off, and,

64 Yoshimi:

65 Nobuko: honma-ni shiroi koo toomee-na:?

Really, white, like this, transparent?

66 Yoshimi: soo na-n.

Is (that) so.

67 Nobuko: $\quad$ yatsu yatta [kedo:, thing (it) was, but,

$68 \rightarrow$ Yoshimi:

69 Nobuko:

70 Yoshimi:

71 Kyoko: [u:n.

Uh-huh.

\section{[ookikatta? \\ big:PT \\ Was (it) big?}

iya chotto chi- chiccha- ma chiccha[ka[tta kedo:, No, (it)'s a little bit small, well, small, but,

[u:n.

Uh-huh.

$[u::: n$.

Uh-huh.

In line 54 Yoshimi asks the storyteller a question itakatta? "Did (it) hurt?”, requesting her to elaborate on the surgery after hearing that the doctor used a needle-like device. She later asks the storyteller another question in line 68 ookikatta? "Was (it) big?" regarding the removed mass mentioned in the prior turns. Excerpt 2 also contains several examples of neutral questions. In Excerpt 2, Kayo relates her blind date experience on the previous day, and the two unknowing story recipients ask many neutral questions to elicit factual information.

Excerpt 2: Shookai "blind date” (neutral questions)

$4 \rightarrow$ Yumi: $a::$, sassoku na-n desu kedo kayo-san kinoo wa doo

INJ right.away COP:ATT-SE COP:POL but (name) yesterday TOP how

[deshi- doo datta-n desu ka::?

FRG how COP:PT-SE COP:POL Q

Oh, without more ado, but Kayo, how was (it) yesterday?

5 Kayo: [hhhhhh[\% $\mathrm{q}$

$6 \rightarrow$ Eri: $\quad$ kinoo naniga atta-n desu ka::?

yesterday what NOM exist:PT-SE COP:POL Q

What did (you) have yesterday?

7 Kayo: shookai ni itte sa:,

(I) went for an introduction, and,

8 Eri: [shookai?

Introduction? 
9 Yumi: [omiai. omiai.

Marriage arrangement. Marriage arrangement.

10 Kayo: soo.

Right.

11 Eri: $e$ ?

What?

12 Kayo: omiai [ya na.

((22 lines omitted.))

(It)'s a marriage arrangement.

35 Yumi: [de::,

And,

36 Kayo: [honde na?

And, you know?

37 $\rightarrow$ Yumi: de, doo deshita-n desu ka.

and how COP:POL:PT-SE COP:POL Q

And how was (it)?

$38 \rightarrow$ Eri: donna hito deshita.

what.kind person COP:POL:PT

What was (he) like?

39

40 Kayo: mitame wa:,

(He) looks like,

41 Eri: un.

Uh-huh.

42 Kayo: nagira ken'ichi?

Ken'ichi Nagira?

$43 \quad$ Eri: $\quad h h h[h$

44 Yumi: $\quad$ [h cho matte. na $(h)[g i(h) r a k e(h) n$ ' $(h) i(h)$ chi. Wait a minute. Ken'ichi Nagira.

45 Eri:

$\left[h h^{\circ} h\right.$

$46 \rightarrow$ Yumi: $\operatorname{mega}[n e ?$

glasses

(Does he wear) glasses?

47 Eri:

[sore wa: ${ }^{\circ} h$

That,

$48 \rightarrow$ Yumi: doo. 
how

How?

49 Eri: $\quad h h$

50 Kayo: ano: chotto yoku itte: baffaroo kimura?

Well, if (I) say (it) a little better, (he looks like) Buffalo Kimura?

$51 \rightarrow$ Eri: $\quad$ hhh $e$ ? nan-sai?

INJ how.old

How old is (he)?

52 Kayo: nijuunana-sai.

27 years old.

53 Eri: $\quad[a::$

O::h.

54 Kayo: [kyoo tanjoobi mitai-na.

It looks like today is (his) birthday.

55 Eri: kyoo ka.

Today.

$56 \rightarrow$ Yumi: $\quad$ u::n. e? kare wa: shokugyoo wa?

yeah INJ he TOP occupation TOP

I see. What's his occupation?

57 Kayo: huriitaa?

Freeter? (=young people who lack full-time employment)

Unknowing story recipient Yumi, who knows that Kayo had a blind date, asks Kayo questions in line 4 doo datta-n desu ka::? "how was (it)” and in line 37 doo deshita-n desu ka. "how was (it)?” Another unknowing story recipient, Eri, who does not know about Kayo’s blind date, initially asks Kayo what she had the day before in line 6. Subsequently, Eri asks Kayo a question regarding Kayo’s date in line 38 donna hito deshita. "What was (he) like?” After Kayo describes the appearance of her date in lines 40 and 42, Yumi asks follow-up questions about his appearance in line 46 mega[ne? "(Does he wear) glasses?” and in line 48 doo. "How?” The two unknowing story recipients continue to ask questions regarding Kayo’s date: Eri’s question in line 51 e? nan-sai? “How old is (he)?” and Yumi’s question in line 56 e? kare wa: shokugyoo wa? "What's his occupation?” Story recipients' questions discussed in Excerpts 1 and 2 above are neutral questions that function merely to prompt elaborated factual information regarding the persons, items, and events described in the current part of the story about the past events that the storyteller is relaying.

In contrast, affect-loaded questions, namely questions layered with affect, function either to elicit the storyteller's affective stance or to display the unknowing story recipients' own affective stance as they request elaborated factual information about the events being relayed, as illustrated in Excerpts 3 and 4 below. In Excerpt 3, while the storyteller Kei and a knowing story recipient ${ }^{4}$ Yoko jointly tell a story about Kei's bizarre behavior during her ski trip to Hokkaido, the northern Japanese island, an unknowing story recipient Tami asks Kei a question.

${ }^{4}$ I define a knowing recipient as "a possible recipient expected to know about an event being reported by a speaker through firsthand experience by having co-experienced the event or through secondhand experience by being informed about the event via the speaker, other people, or other resources” (Koike, 2009). 
Excerpt 3: Ski Trip to Hokkaido (affect-loaded question)

17 Kei: [sukii tsuaa ni itta-n desu ke(h)do(h):, hh

(I) went to a ski tour, but,

18 Megu: $\quad$ h [so(h)no ha(h)na(h)shi ki(h)ite,

(I) heard that story, and,

19 Yoko: [da-dare [to itte-n.

Who did (you) go with?

20 Tami: $\quad[e$ ?

Huh?

21 Kei: $\quad$ [gerendesaito no [hoteru ni= At a hotel near the skiing slope

22 Yoko: [so ya?

Right.

23 Kei: =tomatta-n de(h)su ke(h)do:,

(I) stayed, but,

24 Tami: hai.

Yes.

25 Yoko: de so [kkara ba- basu notte kankoo iku-nen.=

And from there (she) goes sightseeing on a bus.

26 Megu: [meccha wa(h)ra(h)ke(h)ru.

(I) can laugh so much.

27 Yoko: $=[$ nakabi.

The middle day (of a ski tour).

28 $\rightarrow$ Tami: [e. hh huyu no hokkaidoo o desu [ka?

INJ winter GEN (name) ACC COP:POL Q

What? Is (it) in Hokkaido in winter?

29 Kei:

[>soo. soo. soo. $<$

Right. Right. Right.

30 Tami: [meccha tsu-

Very-

31 Megu: [hitori betsukoodoo tte kiite moo watashi mo bikkuri-shite-n moo.

(I) heard (you did) separate activities alone, and I was surprised, too.

From line 17 to line 27 co-storytellers Kei and Yoko say that Kei went to a ski tour and stayed at a hotel near the skiing slope, but that she went sightseeing on a bus (rather than skiing) during the ski tour. The unknowing story recipient Tami then asks Kei a question in line $28 \underline{e}:$ hh huyu no hokkaidoo o desu [ka? "What? Is (it) in Hokkaido in winter?" Tami's question here is used not only to request confirmation from the storyteller Kei but also to display her own affect-her surprise, disbelief, and humor. Excerpt 4, in which the storyteller relays her friend's story about her graduation thesis, also provides another example of an affect-loaded question. 
Excerpt 4: B.A. Graduation Thesis (affect-loaded questions)

1 Sumiko: a de kinoo: sono ato nanka (.) hookago sono: iyo-chan toka to:, Oh, and yesterday after that, after school, well, with Iyo and others,

2 Keiko: un.

Uh-huh.

3 Sumiko: yari-yoru toki: aki-chan mo kite:, when (I) was doing (things), Aki also came, and,

4 Keiko: a soo na- $n$.

Oh, is (that) so.

5 Sumiko: un. shima-sensee no ofisuawaa no ato de.

Yeah. After Professor Shima's office hours.

6

7 Sumiko: de nanka (.) shima-sensee ni:, And like, by Professor Shima,

8 Keiko: un.

Uh-huh.

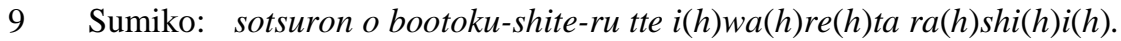

I heard that (she) was told that (she) is desecrating the (B.A.) graduation thesis.

10 $\rightarrow$ Keiko: $\quad \underline{n a(h) n(h) d e:: ? ~ h h h h}$

why

Why?

11 Sumiko: okashii yaroo? $h$

(It)'s funny, isn't it?

12 $\rightarrow$ Keiko: $\quad$ hhhh h do(h)oyu $(h)$ u ko(h)to so(h)re.

how thing that

What does that mean?

13

14 Sumiko: nanka mae no hi ni ganbatte ankeeto o [tsukutte=

Like, on the previous day (she) did her best and made a questionnaire, and,

15 Keiko:

$[h h$

16 Sumiko: =itta-n tte:.

(she) went (to the office hours), (she) said.

((Sumiko’s story continues.))

After the storyteller Sumiko delivers the "story preface” (Sacks, 1974) in line 9 sotsuron o bootoku-shite-ru tte $i(h) w a(h) r e(h) t a r a(h) s h i(h) i(h)$. "I heard that (she) was told that (she) is desecrating the (B.A.) graduation thesis" by her professor, an unknowing story recipient Keiko asks two affect-loaded questions in line 10 
$n a(h) n(h) d e:: ?$ "Why?” and in line 12 do(h)oyu(h)u ko(h)to so(h)re. "What does that mean?” Keiko's questions in lines 10 and 12 function to draw out information about the story being shared by the storyteller, to reveal her own affective stance (i.e., her surprise, disbelief, and humor), and to provide a "go-ahead" response (Koike, 2009; Schegloff, 2007) to Sumiko's story preface, encouraging the storyteller to progress her storytelling sequence. In the subsequent sections from Section 3.2 to Section 3.4, I will examine multimodal aspects (e.g., language, prosody, facial expressions, and body movements) of affect-loaded questions to elucidate unknowing story recipients' practices of asking affect-loaded questions and the participation framework in the storytelling.

\subsection{Emotion Words}

Emotion words, i.e., language that indexes emotions, include such words as adjectives, verbs, particles, and the like, that are related to the expression of emotions. Excerpt 5, in which the storyteller Eiko tells about her miai "marriage arrangement" experience, illustrates a case where an unknowing story recipient elicits the storyteller's emotional state at the time of the event being recounted, using an emotion adjective. Although the unknowing story recipient asks several questions while Eiko is telling her story, I will focus on the affect-loaded question in this excerpt.

Excerpt 5: Miai “marriage arrangement”

16 Eiko: damasareta: toka ne. iya ik-kai honto-ni damasareta [koto ga aru sa:? Like "(I) was deceived". No, (I) have been really deceived once, you know?

17 Shizu: $[h h$

19 Shizu: $\quad$ h [zettai damasarete-ru. $=$ Definitely (you) are deceived.

20 Eiko: [maji de. Seriously.

21 Shizu: =e? sore kimono toka kiru [yoo-na n desu ka? What? Is that like the one (you) wear kimono?

22 Eiko: [chigau-no. tomodachi to: nomu kara issho-ni oide yo: tte yutte chakkari musuko ga ita-no. mu(h)ko(h)o ni(h). hhhh ${ }^{\circ} h h$ No. (My mom) said (she) will have a drink with (her) friend, so come with (her), and cunningly the other side (=her friend) brought (her) son (with her).

$23 \rightarrow$ Shizu: ki-mazukatta desu ka?

feeling.awkward:PT COP:POL Q

Did (you) feel awkward?

24 Eiko: dakara ne:, nanka toriaezu: oya no tomodachi toka yuu to sa:, hora tomodachi-kankee made waruku sase-chau to [nan da shi toka tte iran ki o tsukatte-shimatte:, =

So, you know? Like, for the time being, if (she)'s (my) parent's friend, you know, (it) will be a problem if (I) make their friendship weaker, and so (I) worried about (things) that I didn't have to, and,

25 Shizu: [u::n.

$$
\text { Uh-huh. }
$$

26 Eiko: bai tsukareta yo. koko de kaiwa ga mazui to sore wa sore de mazui to(h)ka(h). hhhhh 
(I) got twice as tired, you know, thinking if (our) conversation is awkward, that itself will be awkward.

27 Shizu: $\quad e$ ? de, atode mukoo kara ki ni itta ki ni innai toka atta-n desu ka?

What? And, did the other side (contact with you), saying (he) likes (you) or doesn't like (you)?

29 Eiko: nanka uchi no oya wa:, Like, my parent,

30 Shizu: un.

Uh-huh.

((Eiko’s story continues.))

From line 16 to line 22, Eiko mentions that she was deceived by her mother and was set up with the son of her mother's friend, without knowing it was a miai "marriage arrangement". The unknowing story recipient Shizu subsequently asks Eiko a question in line 23 ki-mazukatta desu ka? "Did (you) feel awkward?” So far, the storyteller has simply described the event negatively using the indirect passive ${ }^{5}$ damasareta "was deceived", but Shizu's affect-loaded question using the adjective of emotion ki-mazui "feeling awkward" leads the storyteller to express her inner thoughts and feelings more directly and extensively in the subsequent turns.

In line 24, Eiko describes the concerns that she felt at that moment, saying she was worried whether how she treats this marriage arrangement may damage her mother's relationship with her friend. Eiko then explicitly describes her emotional state at that time, using the intensifier and adjective in line 26 bai tsukareta yo. "(I) got twice as tired". She goes on to express her feelings, saying that she was thinking that if their conversation was awkward, that itself would be awkward (and unfavorable), using the partial repetition of the adjective mazui "awkward" that the unknowing story recipient Shizu used in her question in line 23. Excerpt 5 exemplifies how unknowing story recipients' affect-loaded questions using emotion words facilitate a display of affective stance in the storytelling by inviting the storyteller to disclose her inner thoughts and feelings, which might have been left untold had these affect-loaded questions not been asked.

\subsection{Interjections, Prosody, and Body Movements}

Interjections, or what Goffman (1981) calls "response cries” also display affect. Goffman (1981) stated "response cries such as Eek! might be seen as peripheral to the linguist's domain", but they are "creatures of social situations" (p.121) and "natural expressions, namely, signs meant to be taken to index directly the state of the transmitter" (p. 116). In Japanese conversations, the interjections such as $e$ ? "What?" can display different functions and affect depending on the accompanying intonation and body movements (Koike, 2007, 2008), as in Excerpt 6. In Excerpt 6, the unknowing story recipient Kana uses the interjection $e$ ? "What?" to display her affective stance, while the storyteller Shiho relays a story about her trip to Xi'an.

Excerpt 6: Dumpling Full Course (Dinner) in Xi'an

1 Shiho: ato nani shita kke naa. (0.4) nanka hon- nanka honto-ni gyooza no hurukoosu ga moo kyooretsu sugite:, $[h$

What else did (we) do? Like, a dumpling full course (dinner) was really just too much, and,

2 Kana

3 [un.

$$
\text { Uh-huh. }
$$

5wasaki (2013) pointed out that "the indirect passive depicts some psychological impact, usually identified as "psychological adversity," experienced by the human referent denoted by the passive subject” (p. 160). 
4 Shiho: [are::

That,

5 Kana: [gyooza no hurukoosu?

A dumpling full course (dinner)?

6 Shiho: gyooza bakka datta-n desu yo. saisho kara.

(It) had only dumplings. From the beginning.

7

8 Shiho: nanka (0.6) tonikaku gyoozaryoori na-n desu yo:.

Like (they) are all dumpling menus.

9 Kana: un.

Uh-huh.

10 Shiho: ironna shukoo o korashita $[g y o(h) o(h) z a$ na(h)-n de(h)su(h) ke(h)do,

(They) were various different dumplings, but,

11 Kana: [un. un. un.

Uh-huh. Uh-huh. Uh-huh.

12 Shiho: demo shosen gyooza de:,

Still (they) were just dumplings, and,

13 Kana: $h h g$

14 Shiho: dezaato made gyooza de[::,

Even dessert was dumplings, and,

$15 \rightarrow$ Kana:

[e:::? nakami nani:?

INJ inside what

What? What's inside?

16 Shiho: h nanka saigo wa nan- kurumi no ama:i nanka [ga haitta yatsu.

Like, the last (dish) was a thing with some sweet walnut things inside.

17 Kana:

[un.

Uh-huh.

18 Shiho: nanka iron-na gyooza na-n desu yo. honto-ni.

Like (they) are various dumplings, you know. Really.

19 $\rightarrow$ Kana: [akite-koohen?

get.sick.of:TE-come:NEG

Don't (you) get sick of (them)?

20 Shiho: [chicchai no.

Little ones.

21

(1.0) ((Shiho frowns and nods once.)) 
22 Shiho: de atashi wa mada nanka bakubaku tabete-ta [kedo:, And, I was rather, like, devouring (them), but,

23 Kana:

[un. un.

Uh-huh. Uh-huh.

24 Shiho: entaku no (.) hoka no hi- hito toka wa: moo nanka tochuu de nanka ue::

[toka natte-te:,

Other people on the round table really was like ugh, like midway (through the course), and,

25 Kana: [hhh

26 Shiho: hhh

27 Kana: $[h$

28 Shiho: [atashi bakkari koo moo h na(h)n(h)ka(h) q tabete-[te:,

Only I, like, really was eating like this, and,

29 Kana:

[a::. nan-nin de itta-n.

Oh. How many people went with (you)?

30 Shiho: nanka (0.6) watashi wa: chichioya to issho-ni itta-n desu yo. hutari-de.

Like, I went (there) with (my) father, you know. Two of us.

31 Kana: a soo na-n.

Oh, is (that) so.

32 Shiho: [hai.

Yes.

33 Kana: [otoosan to::?

With (your) father?

34 Shiho: $u(h) n$.

Yeah.

From line 1 to line 14, Shiho mentions that she had a dumpling full course dinner in Xi'an and that even dessert was dumplings (Figure 1). Then, the unknowing story recipient Kana asks a question in line 15 e:::? nakami nani:? "What? What's inside?" to elicit more information about the dessert dumplings Shiho had. Kana utters the turn initial interjection $e$ ? "what?", which precedes her question, in an elongated, rising, and exclamatory intonation, as she is moving her head and upper body to the left and slightly leaning backwards, as shown in Figure 2.

By superimposing the interjection $e$ ? "what" over her intonation and body movements described above, Kana displays her own affective stance-surprise and disagreeableness-toward the "assessable" (Goodwin \& Goodwin, 1992) described in the story, i.e., dessert dumplings. Subsequently, Kana asks another affect-loaded question in line 19 akite-koohen? "Don't (you) get sick of (them)?” using the emotion word akite-kuru "get sick of". What is interesting about Kana's question in line 19 is that Kana not only asks a question about Shiho's affective stance, to which Shiho affirmatively answers by frowning and nodding once in line 21 as shown in Figure 3, but also layers it with her own affective stance toward the dumpling-only dinner by the use of a negative question in the non-past tense.

Kana's question akite-koohen? "Don't (you) get sick of (them)" in the negative non-past tense, instead of akita? "Did (you) get sick of (them)?” in the affirmative past-tense, is more generic rather than specific (Goodwin \& 
Goodwin, 1992; Heritage, 2011), and indicates that Kana is not merely inquiring about the storyteller's emotional state about her particular past event, but that she is also displaying her own presumptive emotional state in a general situation of eating the same food throughout a course dinner. Kana's negative question in line 19 falls into one category of negative questions, what Adachi (1999) calls a "dooiyookyuu-gata no hiteegimonbun 'negative question of request-for-agreement type'”. According to Adachi (1999), some types of negative questions carry a bias of the speaker's affirmative judgment, and negative questions of request-for-agreement type are used when the speaker (i.e., questioner) presupposes an affirmative answer based on his or her own knowledge as an experiencer, and function to request the listener (i.e., answerer) to agree on the speaker's presupposition (pp. 66-69) ${ }^{6}$. Thus, in this case Kana uses an affect-loaded negative question to express her own affective stance akite-kuru "get sick of (something)" based on her own judgment, and requests the storyteller Shiho to agree on it. Furthermore, her affect-loaded question in line 19 shifts the course of storytelling from line 22 and leads the storyteller to describe how other people were feeling sick of the dumpling-only dinner. The unknowing story recipient's affect-loaded questions in Excerpt 6 demonstrate that affect-loaded questions can simultaneously elicit elaborated factual information about the story events, draw out the storyteller’s affective stance, and display the story recipient's own affective stance.

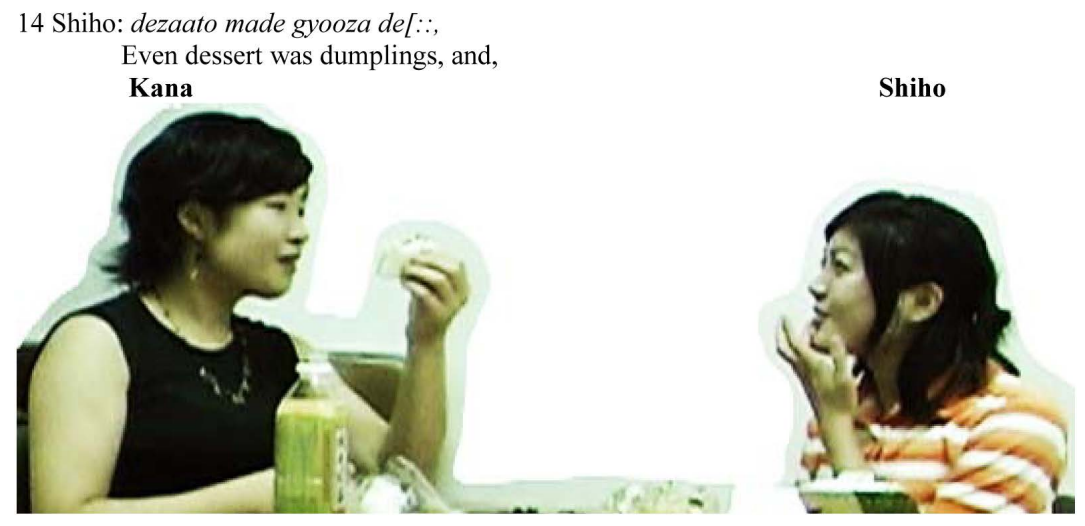

Figure 1. Kana and Shiho’s body movements in line 14.

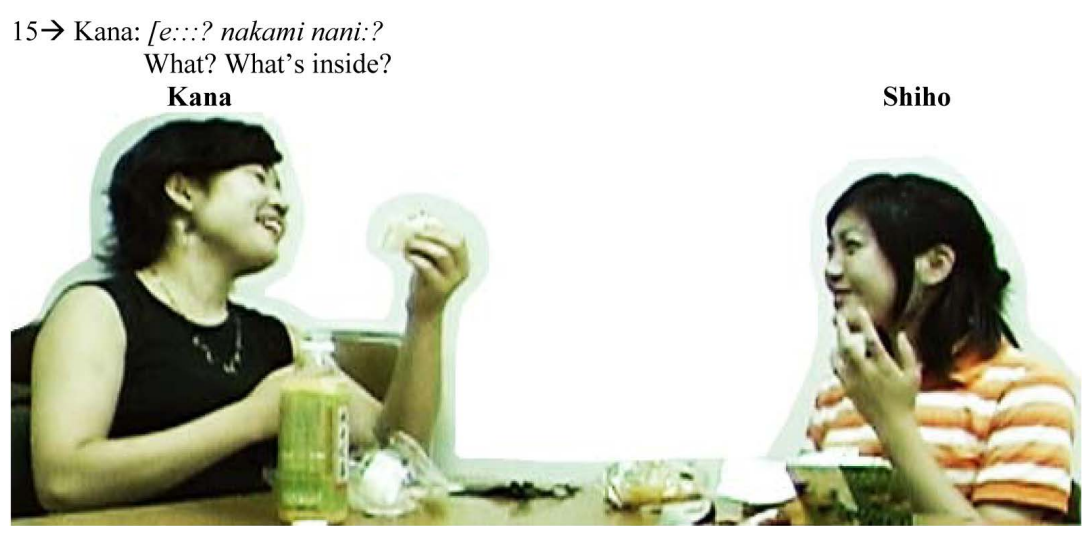

Figure 2. Kana and Shiho's body movements in line 15 (Kana moves her head and upper body to the left and slightly leans backwards).

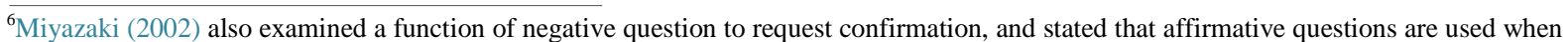
a speaker asks from a neutral position, whereas negative questions are used when a speaker's knowledge and understanding leans toward the opposite to the context (pp. 204-206). A negative question in English can also have an affirmative assumption (Bolinger, 1957). Heritage (2002) found that in broadcast news interviews, the negative interrogative is "argumentative or challenging", is produced as assertion for criticism, and "invites the interviewee to assent to the criticism" (p. 1439). In her analysis of one-on-one second language writing conference interactions between a teacher and an ESL student, Koshik (2005) proposed the term "reversed polarity question (RPQ)", which describes practices beyond the rhetorical question, to refer to a question that conveys "an assertion of the opposite polarity to that of the question" (p. 2). She found that RPQs were used by teachers to challenge and criticize students' written work.
} 


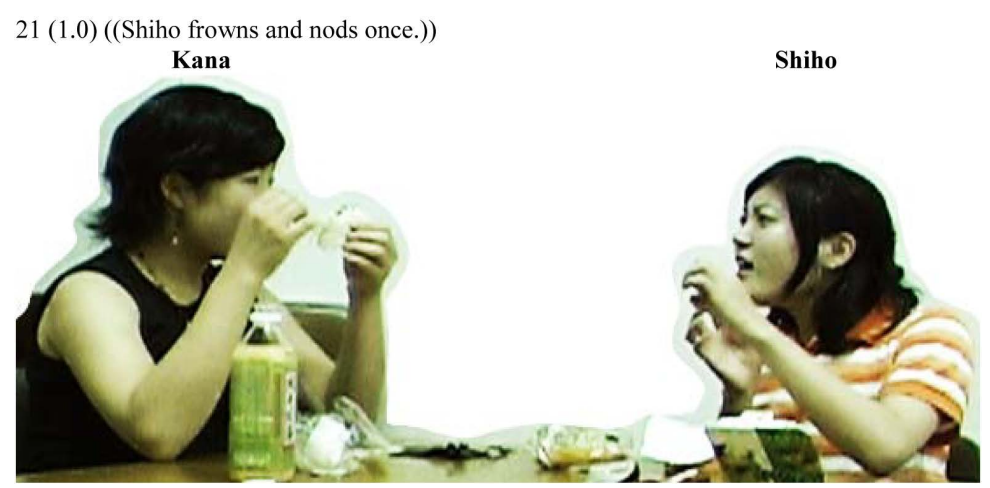

Figure 3. Kana and Shiho's body movements in line 21 (Shiho frowns and nods once).

\subsection{Pre- and Concurrent Laughter}

Participants also superimpose their utterances over pre-/concurrent/post-laughter to show their affective stance toward the events being reported, as in Excerpt 7. Prior to Excerpt 7, which is a continuation of Excerpt 2, the unknowing story recipients asked neutral questions to elicit factual information about Kayo's blind date: his appearance, age, occupation, and so forth. In Excerpt 7, one of the unknowing story recipients Yumi asks another question, an affect-loaded question accompanied by pre- and concurrent laughter.

Excerpt 7: Shookai “blind date” ((Continuation of Excerpt 2))

56 Yumi: u::n. e? kare wa: shokugyoo wa?

I see. What's his occupation?

57 Kayo: huriitaa?

Freeter? (=young people who lack full-time employment)

58 Eri: $a::$

O::h.

59

60 Yumi: itai.

Ouch.

61 Eri: itai.

Ouch.

62 Yumi: geenin ka? $h[h h h h h h h$

Is (he) an entertainer?

63 Eri:

[hhhhhhh

64 Kayo:

[hhhhhhh

65 Yumi: enuesushii ka?

(Is he an apprentice at) the NSC (entertainment school)?

66 Eri: $\quad h h$

67 Kayo: kamo shiren na?

Maybe, you know? 


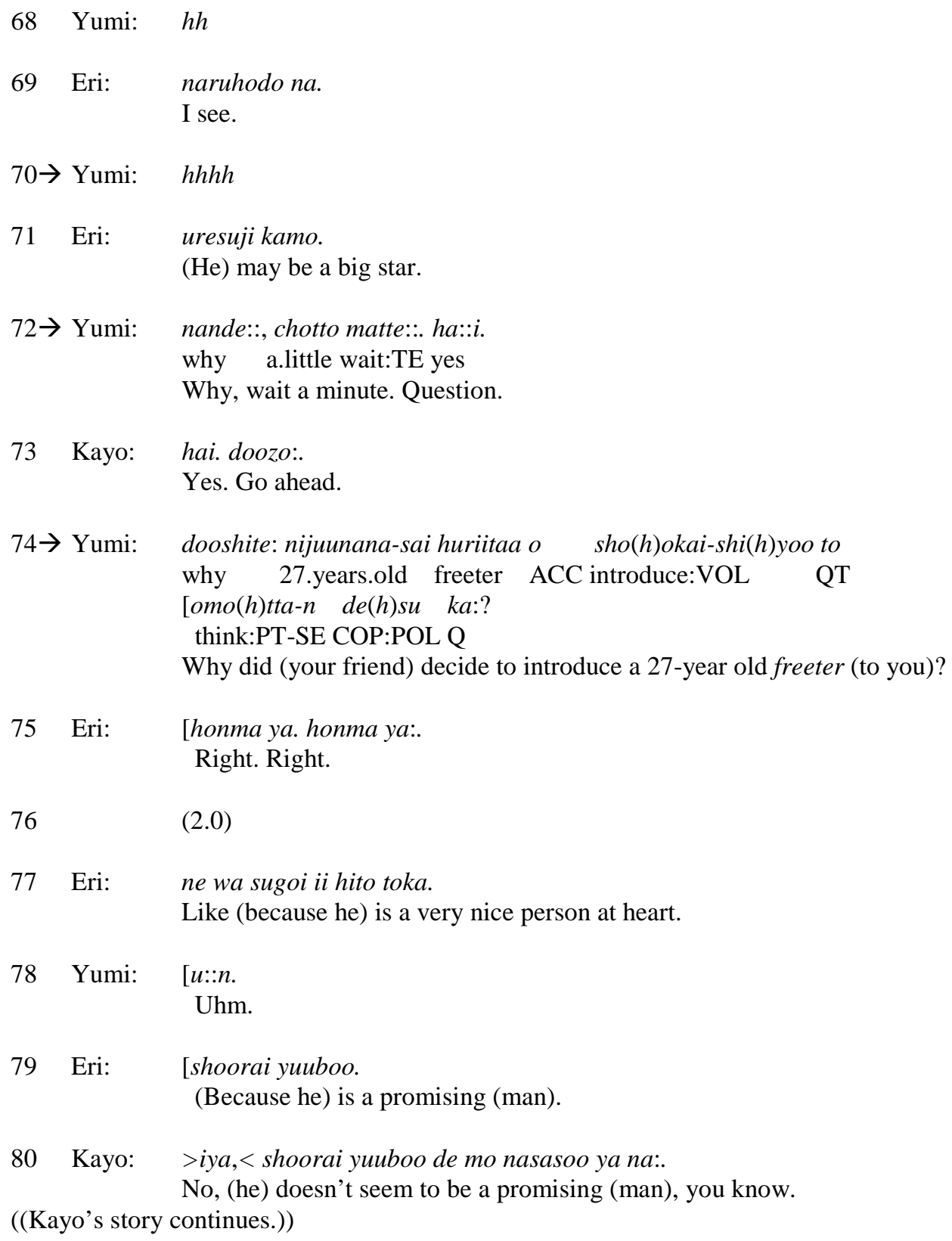

77 Eri: ne wa sugoi ii hito toka.

Like (because he) is a very nice person at heart.

78 Yumi: $[u:: n$.

Uhm.

79 Eri: [shoorai yuuboo.

(Because he) is a promising (man).

80 Kayo: >iya, < shoorai yuuboo de mo nasasoo ya na:.

((Kayo’s story continues.))

No, (he) doesn't seem to be a promising (man), you know.

In response to the unknowing story recipient Yumi's question about her blind date's occupation in line $56 e$ ? kare wa: shokugyoo wa? "What's his occupation?”, the storyteller Kayo replies in line 57 huriitaa? “Freeter?”, which refers to Japanese young people who lack steady full-time employment and typically work at low-income, low-skill, temporary part-time jobs and drift from job to job. After asking two playful joke questions regarding Kayo's blind date's occupation in lines 62 and 65, Yumi first bursts into laughter (pre-laughter) in line 70 as shown in Figure 4, then requests permission to ask her a question in line 72 nande::, chotto matte::. ha::i. "Why, wait a minute. Question.” and finally asks a question with concurrent laughter and a big smile on her face (Figure 5), looking at Kayo in line 74 dooshite: nijuunana-sai huriitaa o sho(h)okai-shi(h)yoo to [omo(h)tta-n de(h) su ka:? "Why did (your friend) decide to introduce a 27-year old freeter (to you)?"

Shookai, which literally means "introduction", is more than just a blind date; it is in fact an informal miai “marriage arrangement” arranged by mutual friends. Yumi requests information about the reason why Kayo’s friend set her up with this freeter, thus the content of her question indicates her seriousness and curiosity. However, Yumi's pre- and concurrent laughter and facial expressions (i.e., a big smile) display her own affective 
stance toward the event described in Kayo's story; namely, it is laughable or ridiculous that Kayo's friend set her up with a 27-year old financially unstable underemployed man who has never held a full-time job as her potential future husband.

In addition, as she asks this affect-loaded question, Yumi also displays her affective stance toward the storyteller Kayo-intimacy, closeness, affection, and sympathy — by her facial expressions (i.e., a big smile) and body movements (i.e., moving her head and upper body very close to Kayo) as shown in Figure 6. As shown in Excerpt 7 above, unknowing story recipients use affect-loaded questions accompanied by pre-, concurrent, post-laughter to elicit factual information from the storyteller while displaying their own affective stance toward the event relayed in the story and toward the storyteller.

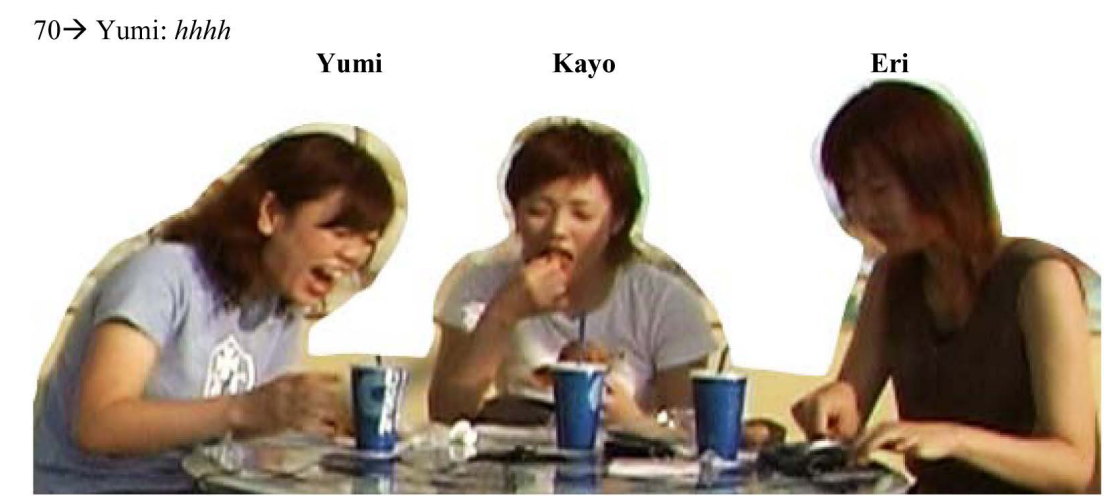

Figure 4. Yumi, Kayo, and Eri’s body movements in line 70 (Yumi bursts into laughter).

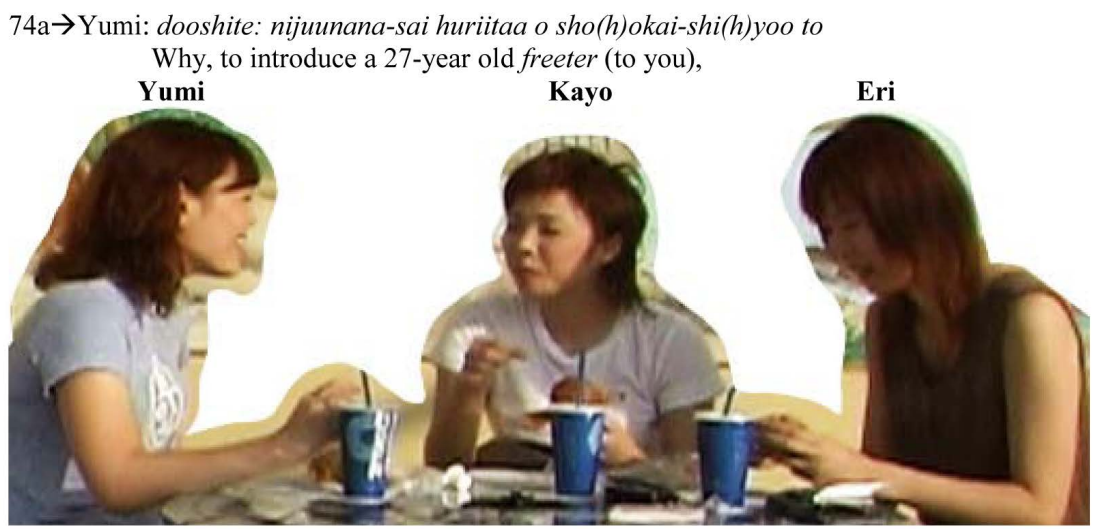

Figure 5. Yumi, Kayo, and Eri’s body movements in line 74a (Yumi asks a question with a big smile on her face).

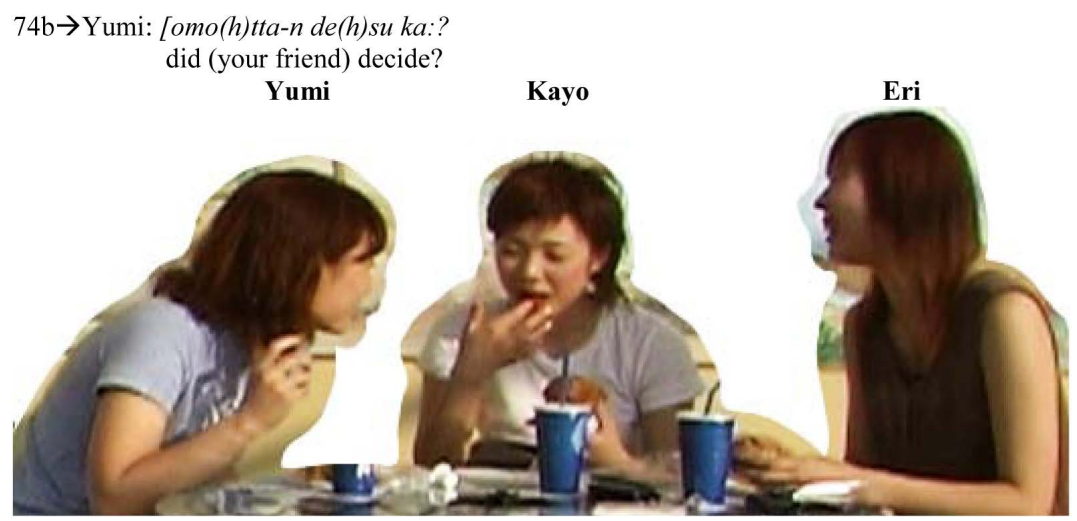

Figure 6. Yumi, Kayo, and Eri’s body movements in line 74b (Yumi leans toward Kayo). 


\subsection{Rhetorical Questions}

Story recipients also employ rhetorical questions, not to elicit information from the storyteller, but merely to emit their affect through self-directed, interrogatively formatted utterances. Although rhetorical questions are "pseudo question expressions" (not "true question expressions") (Minami, 1985), I include rhetorical questions in this analysis of affect-loaded questions in order to examine what enables questions to be construed as rhetorical questions that are used only to display affect (without intention to elicit information from other participants).

According to Bolinger (1957), conducive wh-questions are "uttered in a context which cancels certain otherwise possible answers" (p. 157) due to linguistic and non-linguistic situations; the linguistic factors include "non-neutral expressions" that indicate "undesirability" as in "Who believes such nonsense?” (p. 158). Yet he maintained that rhetorical questions, a sub-group of conducive wh-questions, "cannot be precisely segregated", for questions such as "Who would applaud such a mediocre performance? ... now and then are responded to in terms like Oh, I don't know; maybe she has some friends in the audience” (p. 158). In this section, I will examine how a rhetorical question is construed as such in that it does not make an answer "the relevant second pair part" of an adjacency pair (Schegloff, 2007: p. 78), based on an analysis of linguistic and non-linguistic aspects. Excerpt 8 exemplifies a case where an unknowing story recipient asks a rhetorical question merely to express his affective stance toward the story content, without requesting the storyteller to respond to it by providing information.

Excerpt 8: Rakkyoo-chocolate "pickled shallot chocolate"

4 Fujio: rakkyo mo dame ya.

(I) can't eat pickled shallots, either.

5 Seiji: rakkyo mo dame na-n ya.

It's that (you) can't eat pickled shallots, either.

6 Taku: rakkyo oishikunai-nen kedo:

Pickled shallots are not delicious, but.

7 Fujio: $a$,

Oh,

8 Seiji: a, rakkyo naa.

Oh, pickled shallots, huh.

9 Fujio: a, to:-, tottori ni ne, rakkyo-chokoreeto tte atta rashii-n desu yo mukashi. nde ne,

Oh, I heard that in Tottori there was (a thing) called pickled shallot chocolate a long time ago. And,

$10 \rightarrow$ Seiji: nna getemon dare ga taben-no.

like.that bizarre.thing who NOM eat-SE

Who eats bizarre things like that?

11 Fujio: naka ne, kari tto suru tte yuu shokkan ya, tte yиu imeeji de hutsuu taberu janai desu ka. (You) eat (them) normally having an image that the inside (of pickled shallot chocolate) should have a crispy feel (in the mouth).

13 Fujio: ma, kawaita rakkyo yaro na to. buni tto shita rashii-n desu yo.

Well, (it) will be probably a dried pickled shallot. I heard that (it) had a soft and chewy feel. 
14

15 Seiji: jibun de wa tabete-hen-no.

(You) haven't eaten (it) yourself?

16 Fujio: tabete-nai.

(I) haven't eaten (it).

((Fujio’s story continues.))

In Excerpt 8, after Fujio mentions there was in the past rakkyoo-chokoreeto "pickled shallot chocolate" in Tottori prefecture in line 9, Seiji asks a question in line 10 nna getemon dare ga taben-no. "Who eats bizarre things like that?" Seiji's assessment through the evaluative linguistic expressions using the deictic word nna, which is the contracted form of sonna "like that", and the evaluative word getemon "bizarre thing" expresses Seiji’s disgust toward the assessable, i.e., pickled shallot chocolate. Moreover, Seiji indicates his assessment through non-linguistic modalities, namely facial expressions, gaze, and body movements; when Seiji hears the word rakkyoo-chokoreeto "pickled shallot chocolate", he immediately frowns, lowers the corner of his mouth, and shifts his gaze away from the storyteller and looks down (Figure 7 and Figure 8). He then utters his question as he looks forward with a wry smile on his face, as shown in Figure 9.

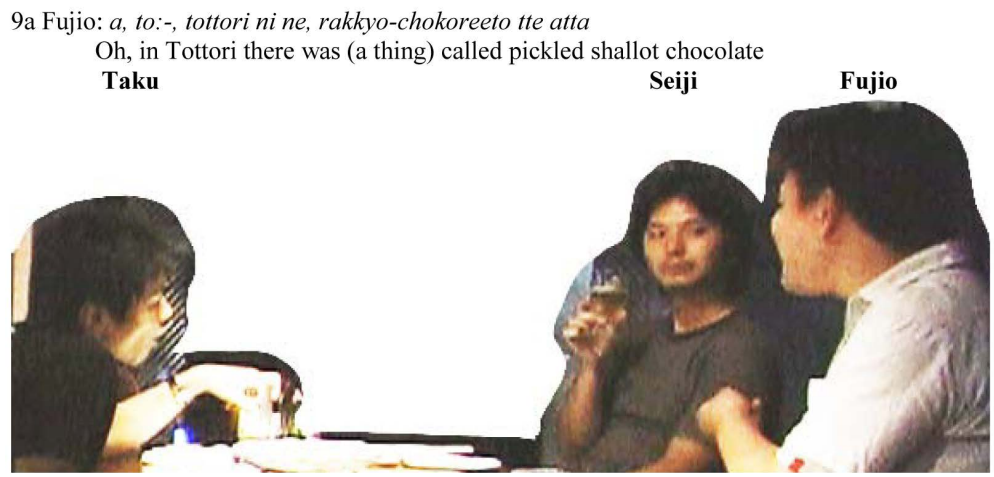

Figure 7. Taku, Seiji, and Fujio’s body movements in line 9a (Seiji looks at Fujio).

9b Fujio: rashii-ndesu yo mukashi. nde ne,

I heard, a long time ago. And,

Seiji

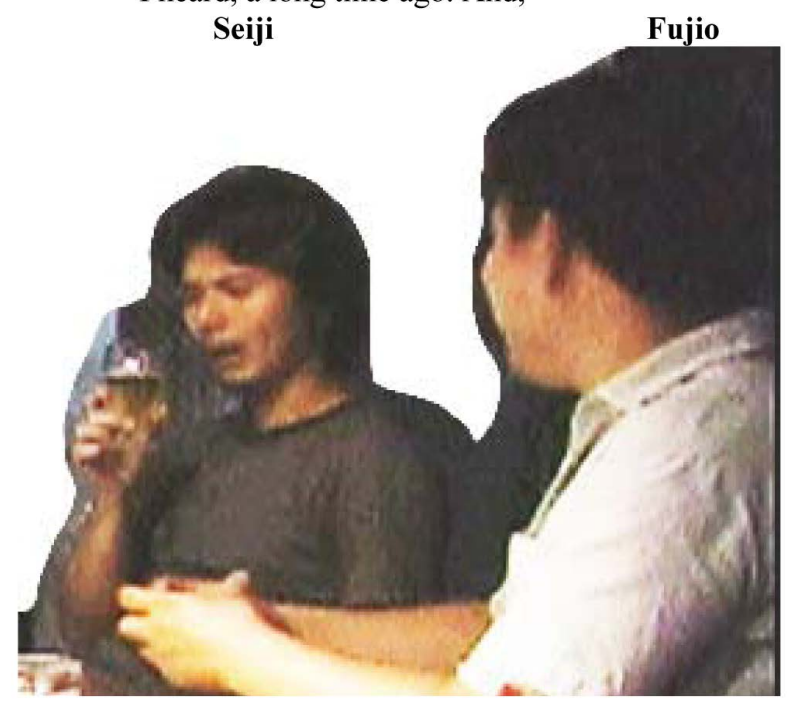

Figure 8. Seiji and Fujio's body movements in line 9b (Seiji frowns, lowers the corner of his mouth, shifts his gaze away from Fujio, and looks down). 
$10 \rightarrow$ Seiji: nna getemon dare ga taben-no.

Who eats bizarre things like that?

Taku

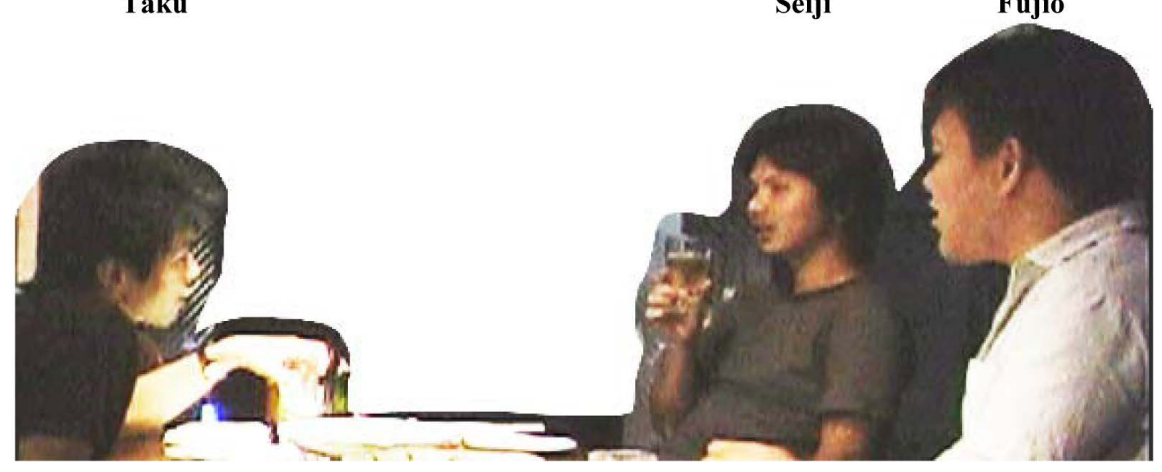

Figure 9. Taku, Seiji, and Fujio’s body movements in line 10 (Seiji asks his question as he looks forward with a wry smile on his face).

Seiji bodily displays “disengagement” (Goodwin, 2002) from Fujio's storyline momentarily as he asks this question, thus indicating his "disalignment" (Stivers, 2008) with respect to the ongoing storytelling activity. Furthermore, Seiji's body movements of turning his face away from the storyteller Fujio in the midst of Fujio's story preface is considered to be his "oppositional alignment" (Goodwin et al., 2012) against Fujio to display his affective stance of disgust toward the target (i.e., pickled shallot chocolate) that Fujio mentions in his story. Seiji's use of evaluative linguistic expressions together with his non-linguistic expressions through his facial expressions, gaze diversion, and body movements described above frames his affect-loaded question as soliloquy (Hasegawa, 2006), thus turning it into a self-directed rhetorical question, which does not regard an answer from the storyteller to be the relevant second pair part ${ }^{7}$. In fact, the storyteller Fujio does not respond to Seiji's question and moves the story forward to continue describing pickled shallot chocolate from line 11. I suggest that the self-directed rhetorical question here is the unknowing story recipient's strategy to display an intensely negative affective stance toward the item or event described in the story without interrupting the storytelling activity.

\subsection{Affiliation and Disaffiliation of Affective Stance}

The unknowing story recipients' affective stance displayed in their affect-loaded questions may or may not be affiliated with the storyteller's own affective stance, and affiliation and disaffiliation of affective stance between the storyteller and unknowing story recipients influence the trajectory of the storytelling sequence. As Goodwin (1986) pointed out, "an audience is not simply a collection of passive listeners, but rather a dynamic entity that can actively influence the interpretation that will be given a speaker's talk" (p. 306). In the next two excerpts (Excerpts 9 and 10), I will explore how affiliation and disaffiliation of affective stance between the storyteller and unknowing story recipients are displayed and negotiated, and how affiliated and disaffiliated unknowing story recipients' affective stance displayed in their affect-loaded questions influences the sequence of storytelling $^{8}$. Excerpt 9 illustrates a case of affiliated affective stance between the storyteller and the unknowing story recipient. In Excerpt 9, where the storyteller Hiromi recounts her experience of watching a videotaped horror drama about a video with her friends, the unknowing story recipient asks an affect-loaded question, and then the storyteller shows her affiliation of affective stance with the unknowing story recipient through allo-repetition of

\footnotetext{
${ }^{7}$ Iwasaki (2014) examined syntactic structures of "internal expressive sentences" which are the sentences that "refer to and reveal directly what the speaker perceives or senses internally" (p. 55), and he stated that "[t]he speaker of true expressive sentences such as itai! "Ouch!” does not have an intention to communicate" (p. 60). It is worth noting here that Seiji's self-directed rhetorical question in Excerpt 8 shares similar characteristics with internal expressive sentences; for example, it directly expresses the speaker's emotion and feeling about what he or she experienced and perceived, it can co-occur with a short outcry vocalization such as ue! "Ugh!" at the turn initial position, and it is not intended to produce a response from other participants.

${ }^{8}$ In contrast to neutral and affect-loaded questions discussed in the present study, Heritage (2011) found that story recipients used "ancillary questions", that is, "somewhat related question[s] about the matter" (p. 164) "for declining empathic affiliation with the position taken by the teller, while simultaneously enforcing a shift in conversational topic" (p. 168).
} 
the recipient's emotion word.

Excerpt 9: "Ring”

18 Hiromi: sono onnaji ryoo ni sunde-ta tomodachi ga: chotto bideo de mitai dorama ga an-nen kedo hitori-de yoo miihin-nen [tte minna o heya ni atsumete:,

Um, (my) friend living in the same dorm said, "(I) have a video drama that (I) want to watch, but (I) can't watch (it) alone”, and (she) gathered everyone (in the dorm) together to (her) room, and,

19 Ikuyo:

$$
\begin{gathered}
{[a::: . h h} \\
\text { O:::h. }
\end{gathered}
$$

20 Hiromi: ${ }^{h} \mathrm{~d}$ de $>$ nanka $<$ (0.2) so- to- saisho nan no hanashi ka wakaran to, And, like, (we) didn’t know what kind of story (it) was at first,

21 Ikuyo: [un.

$$
\text { Uh-huh. }
$$

22 Hiromi: [minna nani nani tte nanka chotto kowai rashii-n [ya kedo tte,= everyone said "What? What?" "Like, (it) seems a little scary, but",

23 Ikuyo: [un. Uh-huh.

24 Hiromi: =e, soo na-n? toka tte koo: okashi tabe-nagara 'h mite-tara:,

"Oh, is (that) so?”, and when (we) were watching (it) while eating snacks like this,

25 Ikuyo: un.

Uh-huh.

26 Hiromi: bideo no [hanashi ya::n.

(it) was a story about a video.

27 $\rightarrow$ Ikuyo: $\quad[$ me(h)cha ko(h)wa(h)i-no::? awfully scary-SE

(It)'s awfully scary?

28 Hiromi: [bideo no [hanashi o bideo de mite-ru kara=

(we) were watching a story about a video on the video, so,

29 Ikuyo: [hhhhhhhhh

30 Junko: [hhhh

$31 \rightarrow$ Hiromi: $\quad=g o(h) t t s u(h) u$ ko(h)wa(h)ku(h)te mo(h)o::. hhhh

(it) was extremely scary, really.

32 Ikuyo: shichueeshon ga issho [na-n ya.

(Your) situation (of watching the video) is the same (as the story of the horror drama).

33 Hiromi: [>soo. soo. soo. $<$

Right. Right. Right. 
((Hiromi’s story continues.))

Prior to Excerpt 9, the participants were talking about a Japanese mystery horror novel called Ring, a novel about a mysterious cursed videotape that was turned into a serial television drama and a movie. Hiromi next launches into storytelling about her experience of watching a TV drama version of Ring that her friend had recorded on a videotape. From line 18 to line 24, the storyteller Hiromi describes the setting of her story: her friend had invited a couple of her friends living in the same dormitory including Hiromi to watch a video together, saying that she could not watch it alone. They were watching the video without knowing the content of the horror drama. Hiromi says that they realized that the drama was about a video in line 26 bideo no [hanashi ya::n. "(it) was a story about a video".

Overlapping with Hiromi’s utterance in line 26, the unknowing story recipient Ikuyo co-constructs ${ }^{9}$ the subordinate conditional tara "if/when" clause of Hiromi's utterance in line 24 and anticipatorily provides a concluding main clause by asking an affect-loaded question in line 27 [me(h)cha ko(h)wa(h)i-no::? "(It)'s awfully scary?” Although Hiromi does not immediately respond to Ikuyo's question and continues to relay her story, she confirms Ikuyo's candidate understanding, thereby showing her affiliation of affective stance with Ikuyo, through the use of syntactically parallel allo-repetition in line 31 go(h)ttsu(h)u ko(h)wa(h)ku(h)te mo(h)o::. "(it) was extremely scary, really". Ikuyo in her question in line 27 uses the intensifier mecha "awfully (Osaka dialect)" and the emotion word kowai "scary", together with concurrent laughter in a shaky voice and knitting her eyebrows, which display the emotional state of being fearful. When Hiromi describes her emotional state during the video-watching event in line 31, she also uses the upgraded intensifier (Pomerantz, 1984) gottsuu "extremely (Osaka dialect)" and the same emotion word kowai "scary" accompanied by concurrent laughter in a shaky voice and wide open eyes to demonstrate how frightened she was by the video. Figure 10 shows how the syntactic pattern, prosody, and body movements of the unknowing story recipient's affect-loaded question are repeated in the storyteller's subsequent turn, thus displaying her affiliated affective stance. As shown in Excerpt 9, when the unknowing story recipient's affective stance is affiliated with the storyteller's, the unknowing story recipient's affect-loaded question is seamlessly incorporated into the storytelling without interrupting the storyline, through the use of linguistic and non-linguistic devices.

In contrast, Excerpt 10 illustrates a conflict situation where the storyteller and unknowing story recipient display disaffiliated affective stances toward the event being reported. Prior to Excerpt 10, a college student, Eri, relayed that although she had had a crush on her current boyfriend Yoshi since high school, it was unrequited love at that point. In Excerpt 10, when Eri tells about a high school incident in which she played Cupid for her female friend who loved Yoshi, the unknowing story recipient Maki displays her strong disaffiliation by asking affect-loaded questions.

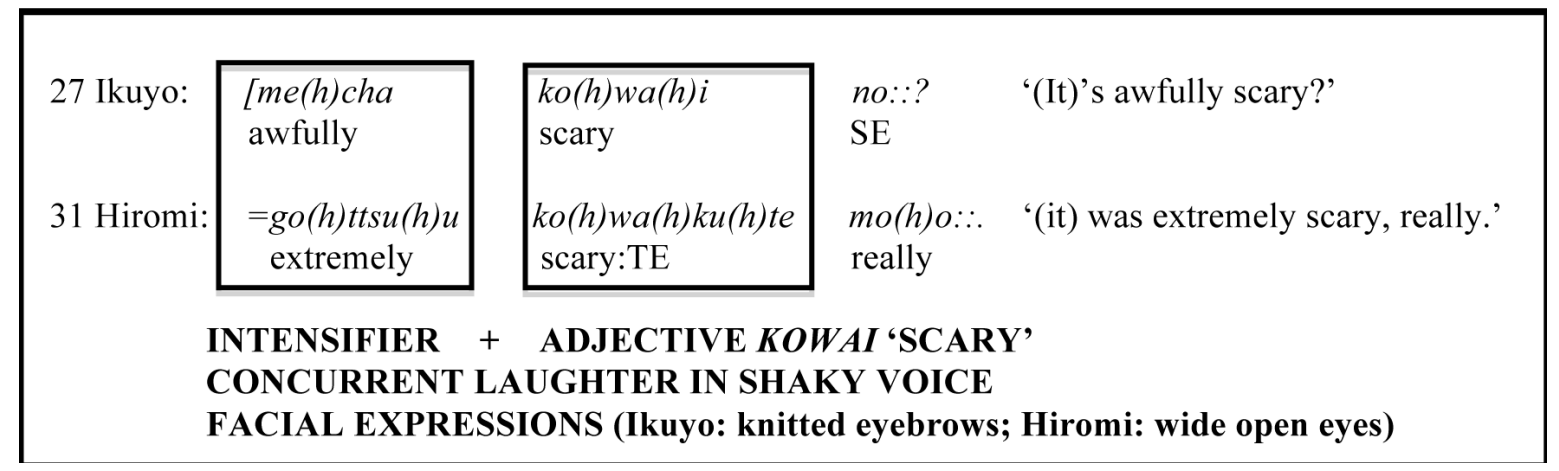

Figure 10. Syntactically parallel allo-repetition in Ikuyo's utterance in line 27 and Hiromi’s utterance in line 31.

\footnotetext{
${ }^{9}$ In his analysis of completion of sentences-in-progress in English conversations, Lerner (1991) stated that the if $X$-then $Y$ is a "compound turn format" that begins with a "turn-initial compound format marker", which "provides the resources for the achievement of a collaboratively constructed sentence” (p. 445). Hayashi (2003) also described “co-participant completion” as "a practice whereby a participant produces an utterance that is grammatically fitted to the ongoing trajectory of another participant's utterance-in-progress and which brings that other participant's utterance to completion” (p. 25). With regard to Japanese storytelling, Koike (2009) showed how an unknowing story recipient uses co-construction in a rising intonation to request confirmation about his or her candidate understanding of the next part of the story.
} 
Excerpt 10: Cupid

$9 \quad$ Eri: $\quad h$ atashi shitte-n da sore o: de na(h)n(h)ka: ji(h)tsu wa: kakure fan wa, It's that I know that. And, like, "to tell you the truth, (your) secret admirers",

10 Maki: ${ }^{\circ}$ un. ${ }^{\circ}$

${ }^{\circ}$ Uh-huh. ${ }^{\circ}$

11 Eri: $\quad$ konna-ni ippai ita-n da yo: mitai-na ${ }^{\circ} \mathrm{kanji}_{\mathrm{de}}{ }^{\circ}$

"it’s that there were this many, you know" ${ }^{\circ}$ kind of, and. ${ }^{\circ}$

12 Maki: sugoi ne::. hh mote[mote datta-n da.

(That)'s amazing, isn't it. It's that (he) was very popular (with girls).

13 Eri: [ [>atashi datte < ik-kai (.) kyuupitto-yaku yatta koto aru mon.

Because I've played Cupid (for someone) once.

$14 \rightarrow$ Maki: $\quad$ nande yan-no so(h)n(h)na $[k o(h) t o(h)$.

why do-SE like.that thing

Why do (you) do such a thing?

$15 \rightarrow$ Eri: $\quad[y a(h) r i t a k u(h) n a k a(h) t t a k e(h) d o,<$ takoo no onna-no-ko de:,

(I) didn’t want to do (it), but (it)'s a girl from a different school, and,

16 $\rightarrow$ Maki: $\quad$ u::n. demo: eri-chan, son toki mo: suki datta-n desho?

yeah but (name) that time also like COP:PT-SE MOD

Yeah. But, you liked (him) at that time, too, didn’t you?

17

18 Eri: $\quad>$ suki da kedo < ienai jan.

(I) like (him), but (I) can’t say (it), you know?

19 Maki: ienai kedo sa::,

(You) can’t say (it), but, you know,

20 Eri: $\quad$ ienai shi:, nanka akiramete-ta bubun mo aru no jibun de:.

(I) can't say (it), and, like, I had somewhat given up (on him) in my (mind).

21 Maki: $u:: n$.

Uh-huh.

((11 lines omitted.))

32 Eri: [honde: (0.6) soo. sono ko: ga suggoi suki de sa, sono onna-no-ko mo juudoo tsuyokatta-no. edo-san tte yuu ne,

And, (0.6) right. That girl really liked (him), and, you know, that girl was also good at Judo. (A girl) named Ms. Edo, you know,

33 Maki: hhhh.

34 Eri: $\quad \operatorname{su}(h) n(h) g o(h) i(h)$, edo seinikuten no musume na-n [da kedo ne:,

Really, (she) is the daughter at Edo Butcher's Shop, but, you know,

((Eri’s story continues.)) 
After relaying how Eri's current boyfriend Yoshi was very popular with girls and had many secret admirers when they were in high school, Eri mentions an incident to illustrate her point, saying in line $13>$ atashi datte< ik-kai (.) kyuupitto-yaku yatta koto aru mon. "Because I've played Cupid (for someone) once". Then, Maki asks the storyteller Eri a question in line 14 nande yan-no so(h)n(h)na [ko(h)to(h). "Why do (you) do such a thing?", while looking at Eri, opening her eyes wide, and knitting her brows as shown in Figure 11.

First, Maki uses a wh-question nande "why", immediately after the storyteller delivered the story preface in line 13, to challenge the storyteller by questioning the reasonable justification for conduct that she reported and strongly imposing accountability on her. As Koshik (2005) noted, wh-questions can be "used to challenge prior utterances or actions" and are "heard as asserting a strong stance toward a prior utterance or action" (pp. 40-41). She also showed that "how" and "why" questions can be used as complaints, as they "ask for an account of an action, but at the same time imply that there is no adequate account available" (Koshik, 2005: p. 54). In addition, "emotionally charged" non-predicate-final utterance in one intonation unit (Ono, 2006) and the evaluative deictic word sonna koto "such a thing" grammatically indicate Maki's negative assessment and affective stance toward the event described.

Furthermore, (1) her facial expressions (i.e., eyes wide open and knitted brows) while gazing at the storyteller, (2) accompanying cynical concurrent laughter in the post-positioned increment (i.e., sonna koto "such a thing"), (3) an emphatic high pitch on the initial word of Maki's question nande "why", and (4) abrupt "declination" (Koike, 2003; Pierrehumbert \& Beckman, 1988) in the overall intonation contour of her question, all express Maki's own intensified affective stance—-surprise, disapproval ${ }^{10}$, resentment, accusation, and irritation—-toward the incident Eri has just described. Through the use of grammar, prosody, and facial expressions, Maki's affect-loaded question in line 14 explicitly indicates her disaffiliation of affective stance from the storyteller's positive assessment, which the storyteller expressed by bragging about an event to illustrate the popularity of her boyfriend during high school.

In the first part of line 15, Eri first admits that the incident described (i.e., helping her female friend get together with the guy Eri loved) was not what she wanted to do, thus showing her affiliation with Maki by saying [ya(h)ritaku(h)naka(h)tta ke(h)do,< “(I) didn't want to do (it), but” with concurrent laughter and smiling with her eyes tightly closed, as shown in Figure 12. Then, she continues to tell her story from the second part of line 15 takoo no onna-no-ko de:, "(it)'s a girl from a different school, and”.

However, rather than providing a continuer to let the storyteller continue telling her story, Maki asks another affect-loaded question in line 16 u::n. demo: eri-chan, son toki mo: suki datta-n desho? "Yeah. But, you liked (him) at that time, too, didn't you?”, prefacing her question with $u:: n$ “yeah” with a vowel elongation in a low pitch and demo "but" to show her partial agreement with Eri (Mori, 1999; Pomerantz, 1984), and using the sentence-final modality expression desho? "right?" to request confirmation and indicate her own assertions indirectly (Hayashi, 2010; Minami, 1985; Miyazaki, 2005; Moriyama, 1989), thus criticizing Eri for her action.

14 $\rightarrow$ Maki: nande yan-no so(h)n(h)na [ko(h)to(h).

Why do (you) do such a thing? Eri

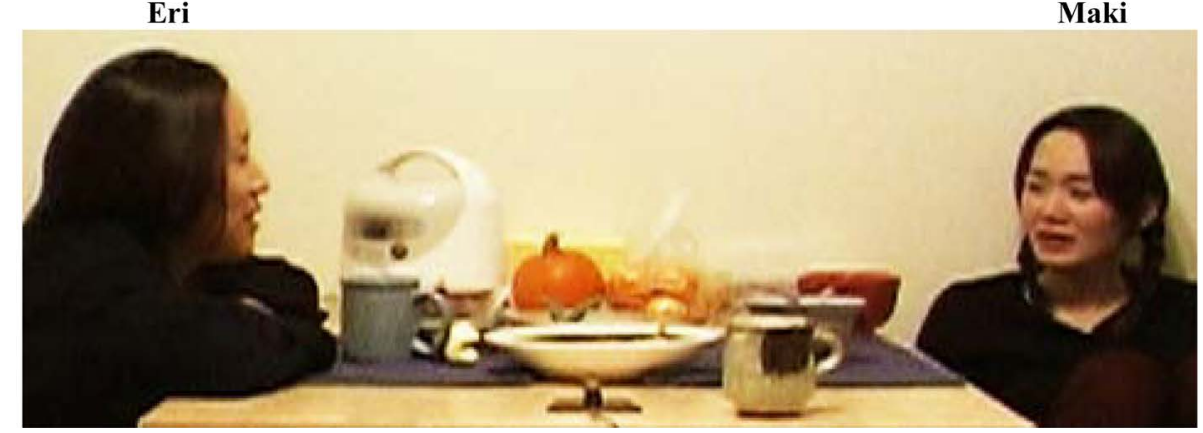

Figure 11. Maki's facial expressions in line 14 (Maki asks her question as she looks at Eri, opens her eyes wide, and knits her brows).

\footnotetext{
${ }^{10}$ Suzuki (2006) observed that “expressions in Japanese which mark unexpectedness of information ('surprise') often simultaneously mark the speaker's negative attitude towards the information ('disapproval')” (p. 155). She argued that "unexpected/unassimilated information is considered to be at the outer margin" which is viewed as negative in Japanese society, thus is associated with "the speaker's negative evaluation” (Suzuki, 2006: p. 167).
} 
$15 \rightarrow$ Eri: $[y a(h)$ ritaku(h)naka(h)tta ke(h)do, $<$

(I) didn't want to do (it), but

Eri

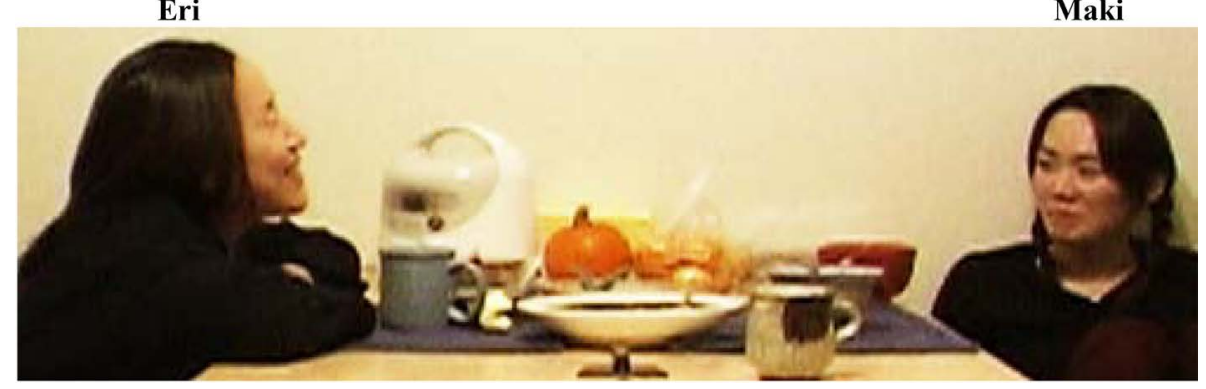

Figure 12. Eri's facial expressions in the first part of line 15 (Eri responds to Maki’s question, smiling with her eyes tightly closed).

In the following turns (lines 18 and 19), although the participants first indicate affiliation of affective stance with each other through allo-repetition (e.g., suki "like" in line 18 and ienai "can't say" in line 19), they subsequently indicate their disaffiliation by the use of the conjunction demo "but" or the conjunctive particle kedo "but" in order to show their partial agreement and mitigate conflict between them. From line 20 until line 32, when Eri finally resumes her story about the Cupid incident, Eri and Maki discuss how Eri felt about Yoshi and how she hid her feelings toward him back in high school. As demonstrated in Excerpt 10, disaffiliation of affective stance between the storyteller and unknowing story recipient toward the event, which was triggered by the unknowing story recipient's affect-loaded question, leads the storyteller to insert a long "side expansion sequence” (Koike, 2009) to elaborate background information before resuming her storytelling.

\section{Conclusion}

The above close analysis of how unknowing story recipients ask affect-loaded questions of the storyteller sheds light on the interactional process of how participants in talk-in-interaction collaboratively express and build affective stance in storytelling through "a gestalt of an emotional display" composed of various different modalities (Ruusuvuori, 2013). I explicated that the unknowing story recipients employed not only lexical and syntactic devices including adjectives of emotions, wh-questions, deictic words such as sonna "like that", and non-predicate-final utterances, but also prosody, facial expressions, body movements, and pre-/concurrent laughter in order to elicit not only factual information but also the emotional states of the storyteller during the event recounted in the story and to display their own affective stance (e.g., surprise, humor, disagreeableness, criticism, resentment, and disgust), which arose during the storytelling activity. Self-directed rhetorical questions were also used to express the unknowing story recipients' own affective stance rather than to elicit factual information and affect from the storyteller.

I also demonstrated how affiliation and disaffiliation of affective stance between storyteller and unknowing story recipients significantly influence the trajectory of storytelling sequence. As Stivers (2008) acutely claimed, "[s]tory responses are concerned not with displaying informedness, but with displaying an affective stance toward the event(s) the story reported” (p. 53). When the affective stance of the storyteller and that of the unknowing story recipient were affiliated, the storyteller indicated affirmation and agreement with the unknowing story recipient through, for example, allo-repetition and congruent prosody. However, when the storyteller's affective stance was not affiliated with the unknowing story recipient's, the storyteller expanded the storytelling by inserting a side sequence of the story to elaborate her stance rather than proceed to the next step of the story, and the storyteller and unknowing story recipient negotiated their affective stance toward the story contents.

Goffman (1981) astutely pointed out as follows: "it is impossible to utter a sentence without coloring the utterance with some kind of perceivable affect, even (in special cases) if only with the emotionally distinctive aura of affectlessness" (p. 120). The analyses in the present study revealed how questions colored with affect through language, prosody, facial expressions, and body movements were exploited to elicit not only factual information but also affect from other participants and to display the speaker's own affect. This study thus serves to illuminate how unknowing story recipients actively participate in co-constructing affective stance as well as contents and storylines in storytelling, and how affective stance is dynamically negotiated between the storyteller and unknowing story recipients in talk-in-interaction. 


\section{Acknowledgements}

Earlier versions of this paper were presented at the 2013 American Association for Applied Linguistics Annual Conference in Dallas, Texas, March 16-19, 2013 and at the $13^{\text {th }}$ International Pragmatics Conference in New Delhi, India, September 8-13, 2013. I am most grateful to Dr. Haruko M. Cook and Dr. Matthew Burdelski for their insightful comments, which helped me to develop earlier versions of my analysis into this paper. I am also deeply indebted to the participants in my data for allowing me to use their conversations, and to Ms. Hisayo Suzuki, the audiences at the above conferences, the Editor, and the referees for their valuable comments on earlier versions of this paper. I am solely responsible for all the mistakes and problems that remain in this paper.

\section{References}

Adachi, T. (1999). Nihongo Gimonbun ni okeru Handan no Shosoo [Aspects of Judgment on Questions in Japanese]. Tokyo: Kurosio Publishers.

Besnier, N. (1990). Language and Affect. Annual Review of Anthropology, 19, 419-451. http://dx.doi.org/10.1146/annurev.an.19.100190.002223

Bolinger, D. L. (1957). Interrogative Structures of American English: The Direct Question. Publication of the American Dialect Society, No. 28. Alabama: University of Alabama Press.

Couper-Kuhlen, E. (2012). Exploring Affiliation in the Reception of Conversational Complaint Stories. In A. Peräkylä, \& M.-L. Sorjonen (Eds.), Emotion in Interaction (pp. 113-146). Amsterdam: John Benjamins Publishing Company. http://dx.doi.org/10.1093/acprof:oso/9780199730735.003.0006

Du Bois, J. W. (2007). The Stance Triangle. In R. Englebretson (Ed.), Stancetaking in Discourse: Subjectivity, Evaluation, Interaction (pp. 139-182). Amsterdam: John Benjamins Publishing Company. http://dx.doi.org/10.1075/pbns.164.07du

Goffman, E. (1981). Forms of Talk. Philadelphia: University of Pennsylvania Press.

Goodwin, C. (1979). The Interactive Construction of a Sentence in Natural Conversation. In G. Psathas (Ed.), Everyday Language: Studies in Ethnomethodology (pp. 97-121). New York: Irvington Publishers.

Goodwin, C. (1984). Notes on Story Structure and the Organization of Participation. In M. Atkinson, \& J. Heritage (Eds.), Structures of Social Action: Studies in Conversation Analysis (pp. 225-246). Cambridge: Cambridge University Press.

Goodwin, C. (1986). Audience Diversity, Participation and Interpretation. Text, 6, 283-316. http://dx.doi.org/10.1515/text.1.1986.6.3.283

Goodwin, C. (2002). Time in Action. Current Anthropology, 43, 19-35. http://dx.doi.org/10.1086/339566

Goodwin, C. (2007). Participation, Stance, and Affect in the Organization of Activities. Discourse and Society, 18 , 53-73. http://dx.doi.org/10.1177/0957926507069457

Goodwin, C., \& Goodwin, M.H. (1992). Assessments and the Construction of Context. In A. Duranti, \& C. Goodwin (Eds.), Rethinking Context: Language as an Interactive Phenomenon (pp. 147-189). Cambridge: Cambridge University Press.

Goodwin, M. H. (1990). He-Said-She-Said: Talk as Social Organization among Black Children. Bloomington and Indianapolis: Indiana University Press.

Goodwin, M. H. (2006). Participation, Affect, and Trajectory in Family Directive/Response Sequences. Text \& Talk, 26, 515-543. http://dx.doi.org/10.1515/TEXT.2006.021

Goodwin, M. H., Cekaite, A., \& Goodwin, C. (2012). Emotion as Stance. In A. Peräkylä, \& M.-L. Sorjonen (Eds.), Emotion in Interaction (pp. 6-41). Amsterdam: John Benjamins Publishing Company.

http://dx.doi.org/10.1093/acprof:oso/9780199730735.003.0002

Hasegawa, Y. (2006). Embedded Soliloquy and Affective Stances in Japanese. In S. Suzuki (Ed.), Emotive Communication in Japanese (pp. 209-229). Amsterdam: John Benjamins Publishing Company. http://dx.doi.org/10.1075/pbns.151.11has

Hayano, K. (2013). Question Design in Conversation. In J. Sidnell, \& T. Stivers (Eds.), The Handbook of Conversation Analysis (pp. 395-414). West Sussex: Blackwell Publishing Ltd.

Hayashi, M. (2003). Joint Utterance Construction in Japanese Conversation. Amsterdam: John Benjamins Publishing Company. http://dx.doi.org/10.1075/sidag.12

Hayashi, M. (2010). An Overview of the Question-Response System in Japanese. Journal of Pragmatics, 42, $2685-2702$. http://dx.doi.org/10.1016/j.pragma.2010.04.006

Heritage, J. (2002). The Limits of Questioning: Negative Interrogatives and Hostile Question Content. Journal of Pragmatics, 34, 1427-1446. http://dx.doi.org/10.1016/S0378-2166(02)00072-3

Heritage, J. (2011). Territories of Knowledge, Territories of Experience: Empathic Moments in Interaction. In T. Stivers, L. Mondada, \& J. Steensig (Eds.), The Morality of Knowledge in Conversation (pp. 159-183). Cambridge: Cambridge Uni- 
versity Press. http://dx.doi.org/10.1017/CBO9780511921674.008

Iwasaki, S. (2013). Japanese: Revised Edition. Amsterdam: John Benjamins Publishing Company. http://dx.doi.org/10.1075/loall.17

Iwasaki, S. (2014). Grammar of the Internal Expressive Sentences in Japanese. In K. Kabata, \& T. Ono (Eds.), Usage-Based Approaches to Japanese Grammar: Towards the Understanding of Human Language (pp. 55-83). Amsterdam: John Benjamins Publishing Company. http://dx.doi.org/10.1075/slcs.156.07iwa

Jefferson, G. (1984a). On Stepwise Transition from Talk about a Trouble to Inappropriately Next-Positioned Matters. In M. Atkinson, \& J. Heritage (Eds.), Structures of Social Action: Studies in Conversation Analysis (pp. 191-222). Cambridge: Cambridge University Press.

Jefferson, G. (1984b). On the Organization of Laughter in Talk about Troubles. In M. Atkinson, \& J. Heritage (Eds.), Structures of Social Action: Studies in Conversation Analysis (pp. 346-369). Cambridge: Cambridge University Press.

Koike, C. (2003). An Analysis of Increments in Japanese Conversation in Terms of Intonation and Grammar. In P. M. Clancy (Ed.), Japanese/Korean Linguistics (Vol. 11, pp. 67-80). Stanford: CSLI Publications.

Koike, C. (2007). E?-Prefaced Utterance in Japanese: A Discourse Particle Projecting a Question. Paper Presented at the 2007 American Association for Applied Linguistics Conference, Costa Mesa, 21-24 April 2007.

Koike, C. (2008). Kandooshi E no Kinoo to Intoneeshon to Higengokoodoo ni kansuru Ichikoosatsu [An Analysis of Interjection E in terms of Functions, Intonation, and Body Movements]. Proceedings of the $22^{\text {nd }}$ Japanese Association of Sociolinguistic Sciences Conference, Nagoya, 58-61.

Koike, C. (2009). Interaction in Storytelling in Japanese Conversations: An Analysis of Story Recipients' Questions. Ph.D. Thesis, Los Angeles: University of California, Los Angeles.

Koshik, I. (2005). Beyond Rhetorical Questions: Assertive Questions in Everyday Interaction. Amsterdam: John Benjamins Publishing Company. http://dx.doi.org/10.1075/sidag.16

Labov, W. (1972). Language in the Inner City: Studies in the Black English Vernacular. Philadelphia: University of Pennsylvania Press.

Lerner, G. (1991). On the Syntax of Sentences-in-Progress. Language in Society, 20, 441-458. http://dx.doi.org/10.1017/S0047404500016572

Lindström, A., \& Sorjonen, M.-L. (2013). Affiliation in Conversation. In J. Sidnell, \& T. Stivers (Eds.), The Handbook of Conversation Analysis (pp. 350-369). West Sussex: Blackwell Publishing Ltd.

Maynard, S. K. (1989). Japanese Conversation: Self-Contextualization through Structure and Interactional Management. Norwood, NJ: Ablex Publishing Corporation.

Maynard, S. K. (2002). Linguistic Emotivity: Centrality of Place, the Topic-Comment Dynamic, and an Ideology of Pathos in Japanese Discourse. Amsterdam: John Benjamins Publishing Company. http://dx.doi.org/10.1075/pbns.97

Minami, F. (1985). Shitsumonbun no Koozoo [The Structure of Question Sentence]. In S. Mizutani (Ed.), Asakura Nihongo Shinkooza 4: Bunpoo to Imi II [Asakura Japanese New Lecture Series 4: Grammar and Meaning II] (pp. 39-74). Tokyo: Asakura Shoten.

Miyazaki, K. (2002). Kakunin Yookyuu [Confirmation Request]. In K. Miyazaki, T. Adachi, H. Noda, \& S. Takanashi (Eds.), Modaritii [Modality] (pp. 203-227). Tokyo: Kurosio Publishers.

Miyazaki, K. (2005). Gendai Nihongo no Gimon Hyoogen: Utagai to Kakunin Yookyuu [Interrogative Expressions of Modern Japanese: Doubt and Confirmation Request]. Tokyo: Hitsuji Shoboo.

Mori, J. (1999). Negotiating Agreement and Disagreement in Japanese. Amsterdam: John Benjamins Publishing Company. http://dx.doi.org/10.1075/sidag.8

Moriyama, T. (1989). Ninshiki no Muudo to Sono Shuuhen [Mode of Recognition and Its Periphery]. In Y. Nitta, \& T. Masuoka (Eds.), Nihongo no Modaritii [Modality in Japanese] (pp. 57-120). Tokyo: Kurosio Publishers.

Ochs, E. (1996). Linguistic Resources for Socializing Humanity. In J. Gumperz, \& S. Levinson (Eds.), Rethinking Linguistic Relativity (pp. 407-437). Cambridge: Cambridge University Press.

Ochs, E., \& Capps, L. (2001). Living Narrative: Creating Lives in Everyday Storytelling. Cambridge: Harvard University Press.

Ochs, E., Schegloff, E. A., \& Thompson, S. A. (1996). Interaction and Grammar. Cambridge: Cambridge University Press. http://dx.doi.org/10.1017/CBO9780511620874

Ochs, E., \& Schieffelin, B. (1989). Language Has a Heart. Text, 9, 7-25. http://dx.doi.org/10.1515/text.1.1989.9.1.7

Ono, T. (2006). An Emotively Motivated Post-Predicate Constituent Order in a “Strict Predicate Final” Language: Emotion and Grammar Meet in Japanese Everyday Talk. In S. Suzuki (Ed.), Emotive Communication in Japanese (pp. 139-153). Amsterdam: John Benjamins Publishing Company. http://dx.doi.org/10.1075/pbns.151.07ono 
Pierrehumbert, J., \& Beckman, M. E. (1988). Japanese Tone Structure. Cambridge: MA: MIT Press.

Pomerantz, A. (1984). Agreeing and Disagreeing with Assessments: Some Features of Preferred/Dispreferred Turn Shapes. In M. Atkinson, \& J. Heritage (Eds.), Structures of Social Action: Studies in Conversation Analysis (pp. 57-101). Cambridge: Cambridge University Press.

Raymond, G. (2003). Grammar and Social Organization: Yes/No Interrogatives and the Structure of Responding. American Sociological Review, 68, 939-967. http://dx.doi.org/10.2307/1519752

Ruusuvuori, J. (2013). Emotion, Affect and Conversation. In J. Sidnell, \& T. Stivers (Eds.), The Handbook of Conversation Analysis (pp. 331-349). West Sussex: Blackwell Publishing Ltd.

Ruusuvuori, J., \& Peräkylä, A. (2009). Facial and Verbal Expressions in Assessing Stories and Topics. Research on Language and Social Interaction, 42, 377-394. http://dx.doi.org/10.1080/08351810903296499

Sacks, H. (1974). An Analysis of the Course of a Joke's Telling in Conversation. In R. Bauman, \& J. Sherzer (Eds.), Explorations in the Ethnography of Speaking (pp. 337-353). Cambridge: Cambridge University Press.

Sacks, H. (1992). Lectures on Conversation. Oxford: Blackwell.

Schegloff, E. A. (2007). Sequence Organization in Interaction: A Primer in Conversation Analysis (Vol. 1). Cambridge: Cambridge University Press. http://dx.doi.org/10.1017/CBO9780511791208

Stivers, T. (2008). Stance, Alignment, and Affiliation during Storytelling: When Nodding Is a Token of Affiliation. Research on Language and Social Interaction, 41, 31-57. http://dx.doi.org/10.1080/08351810701691123

Suzuki, S. (2006). Surprise and Disapproval: On How Societal Views of the Outside Correlate with Linguistic Expressions. In S. Suzuki (Ed.), Emotive Communication in Japanese (pp. 155-171). Amsterdam: John Benjamins Publishing Company. http://dx.doi.org/10.1075/pbns.151.08suz

Tannen, D. (1984). Conversational Style: Analyzing Talk among Friends. Norwood, NJ: Ablex Publishing Corporation.

Weber, E. (1993). Varieties of Questions in English Conversation. Amsterdam: John Benjamins Publishing Company. http://dx.doi.org/10.1075/sidag.3

Wilce, J. M. (2009). Language and Emotion. Cambridge: Cambridge University Press. http://dx.doi.org/10.1017/CBO9780511626692 


\section{Appendix}

\section{Transcription Conventions}

(Adapted from Ochs, Schegloff, \& Thompson, 1996: pp. 461-465)

In the English translation, words that are not verbally stated in Japanese are in parentheses.

$\begin{array}{llll}\text {. } & \text { falling intonation } & {[} & \text { overlap } \\ \text {, } & \text { continuing intonation } & (0.5) & \text { silence; in tenths of a second } \\ ? & \text { rising intonation } & (()) & \text { nonverbal behavior } \\ ! & \text { exclamatory intonation } & \uparrow \downarrow & \text { sharper rises or falls in pitch } \\ : & \text { vowel lengthening } & >< & \text { compressed utterances } \\ = & \text { "latched” utterances } & \mathrm{h} & \text { laughter } \\ \text { - } & \text { a cut-off or self-interruption } & (\mathrm{h}) & \text { laughter within a word } \\ \text { word } & \text { emphasis by loudness or high pitch } & { }^{\circ} \mathrm{h} & \text { inbreath }\end{array}$

\section{Abbreviations of Glosses}

$\begin{array}{lll}\text { ACC: accusative } & \text { MOD: modality } & \text { Q: question marker } \\ \text { ATT: attribute form } & \text { NEG: negative } & \text { SE: sentence extender } \\ \text { COP: copula } & \text { NOM: nominative } & \text { TE: the te-form } \\ \text { FRG: fragments } & \text { POL: polite form } & \text { TOP: topic marker } \\ \text { GEN: genitive } & \text { PT: past } & \text { VOL: volitional form }\end{array}$

